\title{
Solving the 1980s' Velocity Puzzle: A Progress Report
}

\author{
Courtenay C. Stone and Daniel L. Thornton
}

$\mathbf{T}$ between nominal income and the money stock. In its simplest form, the quantity theory of money states that nominal income is equal to the money stock multiplied by its velocity. If velocity is reasonably stable, changes in the money stock have predictable consequences on nominal income; if the money stock is controllable as well, the quantity theory has useful implications for economic policy.' The relationship between money growth and inflation can be derived from the quantity theory framework by "breaking up" nominal income into its two components - the price level and real output. Thus, the stability of the moneyprice link, holding real output constant, is also related closely to the stability of velocity.

For over a third of a century - from 1946 to 1981 the growth of the velocity of money, measured as the ratio of gross national product (GNP) to the narrow money stock (M1), was stable. Its stability contributed

Courtenay C. Stone is a senior economist and Daniel L. Thornton is a research officer at the Federal Resenv Bank of St. Louis. Rosemarie V. Mueller provided research assistance. The authors would also like to thank Michael Darby for helpful suggestions on an earlier draft.

The money stock need not be perfectly controlable; neither, for that matter, must velocity be constant. Movements in velocity (or its growth), however, must be explainable by the behavior of the variables that influence it. This idea, fundamental to macroeconomic policy, was developed by Friedman (1956). See Thornton (1983) for a discussion of the role of velocity for policy purposes. to the rise of monetarism and the adoption of monetary aggregate targets by the Federal Reserve and other centmal banks around the world. Its stability also resulted in two empirically based rules of thumb that came to be used fairly successfully as guides to money growth's effects on income and inflation. Now, how ever, analysts believe that these rules have failed to explain the course of income and inflation during the 1980s, due to a relatively sudden and unanticipated drop in velocity.

Given the important role that velocity plays in economic and policy analysis, it is not surprising that considerable effort has been devoled to solving this velocity puzzle. Unfortunatey, these efforts have produced a welter of competing and occasionally confusing explanations. To bring some order to this disarray, this aticle highlights the problems that have resulted from the puzzling behavior of velocity in recent years and examines the more prominent explanations of the velocity puzzle.

Because the concept of velocity stems directly from the theory of the demand for money, anything that affects velocity can be related to some aspect of the demand for money. (See shaded insert on the follow ing page. Because the demand-for-money approach is likely to be less intuitive to the general reader, however, we will discuss the vartous explanations of the velocity puzzle in terms of velocity itself. 


\section{Velocity and the Demand for Money}

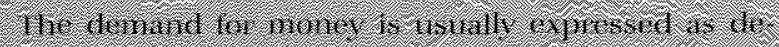

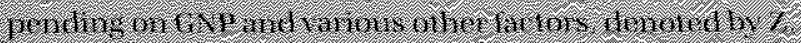

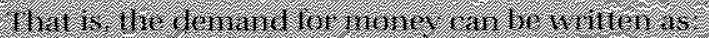

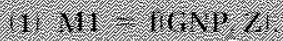

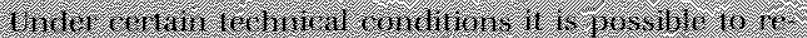

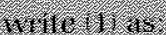

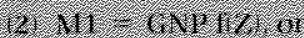

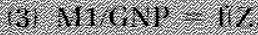

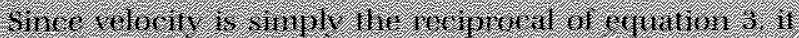

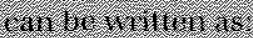

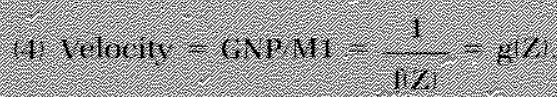

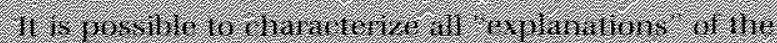

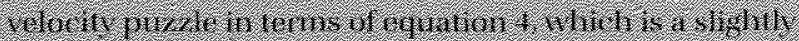

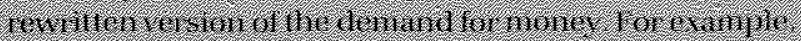

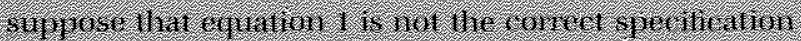

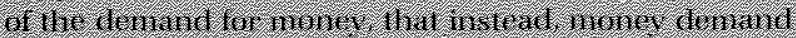

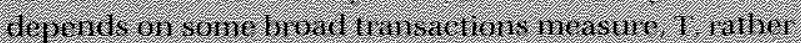

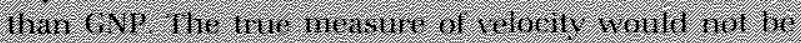

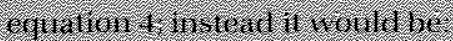

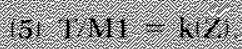

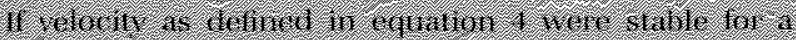

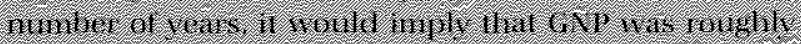

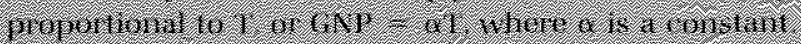

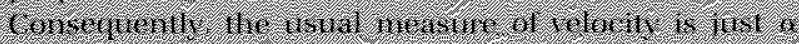

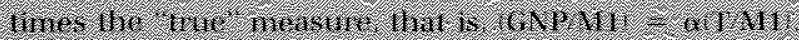

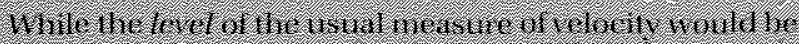

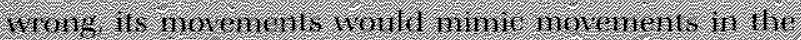

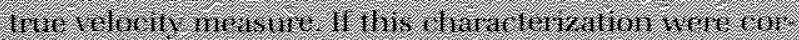

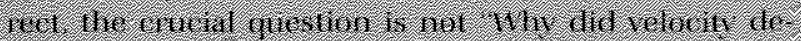

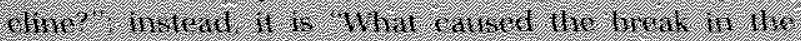

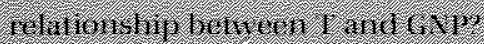

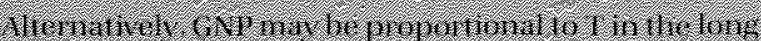

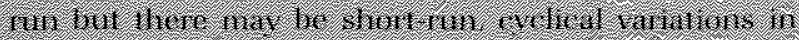

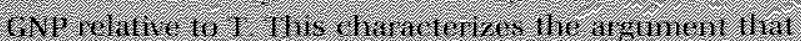

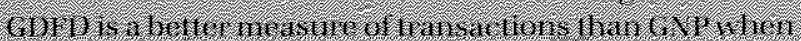

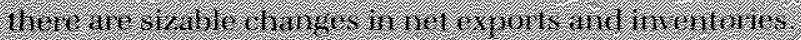

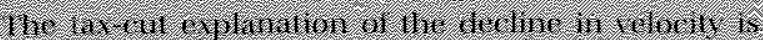

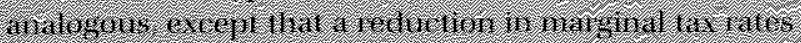

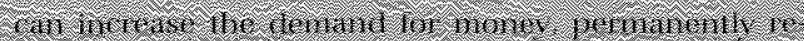

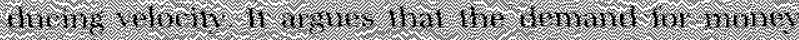

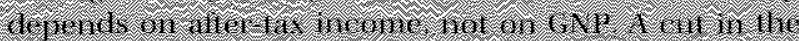

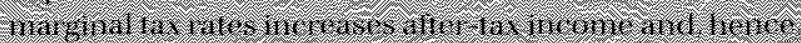

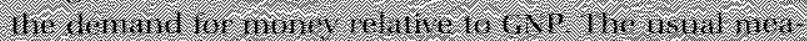

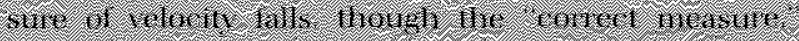

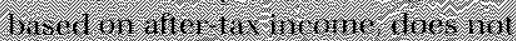

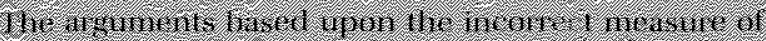

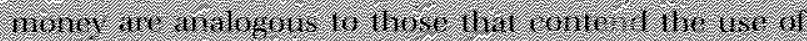

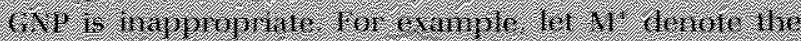

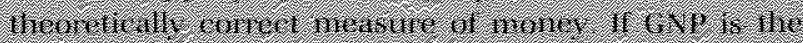

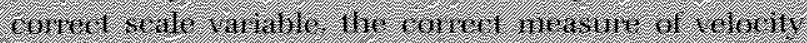

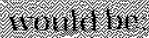

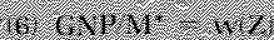

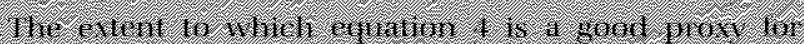

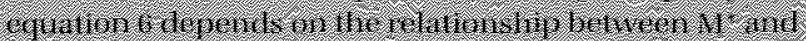

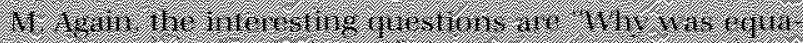

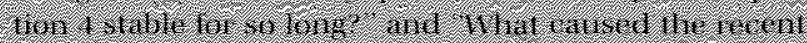

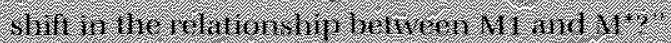

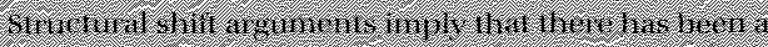

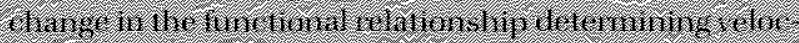

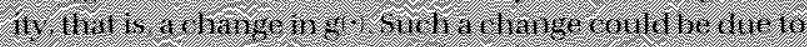

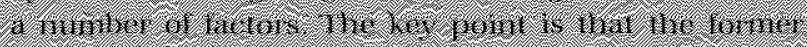

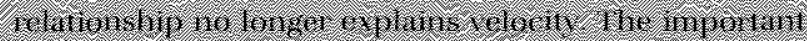
H.

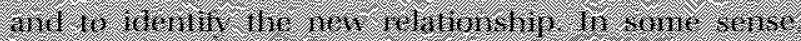

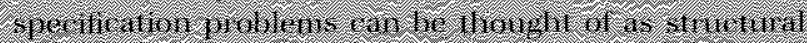

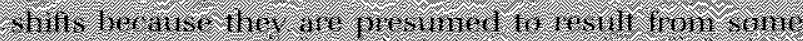

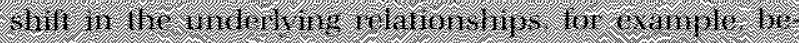

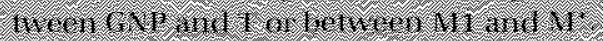

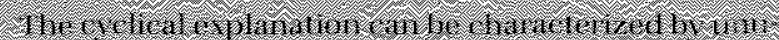

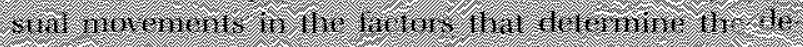

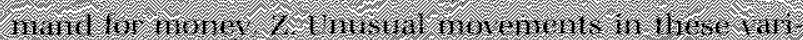

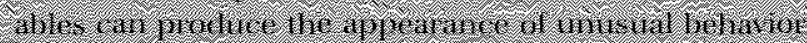

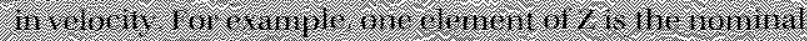

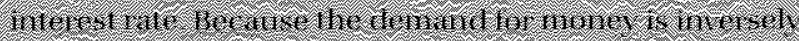

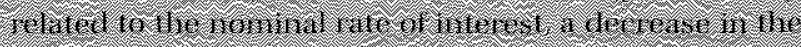

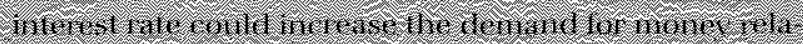

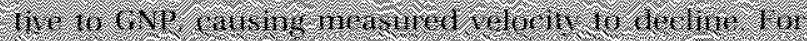

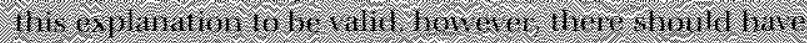

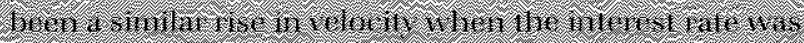

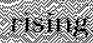




\section{WHAT WENT WRONG AND WHEN?}

Two fundamental relationships between $\mathrm{M} 1$ and specific economic measures have been supported enpirically for decades. One relationship is the link between money and GNP, a measure of total income in the economy. The second relationship is the link be tween money and prices. Charts 1 and 2 show the dramatic changes in these relationships that occured during the 1980 s.

Chart 1 depicts the behavior of the income velocity GNP divided by M1 for the past 40 years; as the chart suggests, something unusual occumed to velocity around 1982. From 1946 through 1981 , it pose fairly steadily at about 3.6 percent peryear; since then, it has declined at annual rate of about 2.4 perent.

Chart 2 shows the relationship since 1948 between annual infation las measured by the growth of the GNP deflatos and the average growth in Mi over a three-year period; use of M1's trend growth is designed to capture the longrun impact of money on prices. While the rate of inflation deviated from the trend growth of M1, sometimes substantially, from 1948 to 1981, the deviations generally were temporary. More importantly, the larger deviations were attributable to non-monetary events for example, government mandated wage price controls, OPEC ail price actions and the like). Since 1982, however, inflation has been substantially and persistently below the trend growth in M1. These deviations are not easily attributable to a specific non-monetary event.

Numerous attempts have been made to explain the recent changes in velocity. In this paper, these explanations are grouped loosely into three categories: misspecification, a ponmanteau category we call "struc" turel shifts" and cyclical factors."

\section{MISSPECIFICATION}

The most widely used velocity measure, the income velocity of $\mathrm{ML}$, is calculated by dividing nominal GNP by the nominal stock of M1. Both GNP and MI are empirical counterparts to theoretical concepts that appear in various theories of the demand for money. One explanation for the shift in velocity is that GNP or

2A number of these are considered in studies by Rasche (1986), Darby et. al. (1987). Hetzel (1987), Trehan and Walsh (1987) and Kretzmer and Porter (1987). The categories considered here are somewhat more general than those considered by Trehan and Walsh.
M1 or both have become less reliable proxies for their corresponding theoretical concepts. This problem is called a specification problem."

\section{GNP Vs. Transactions Measures}

One specification problem could arise if money is held primarily to make daty transactions. If these include intermediate and financial transactions, the usual velocity measure could vary with changes in the proportion of such transactions relative to transaclions on final goods and services. Because GNP measures only final output, it will differ widely from the level of expenditures on all transactions. In this case, GNP is a useful proxy for total transactions only if the proportion of GNP to total transactions remains relatively constant.

This problem can manifest itself in several ways. For example, suppose consumers purchase more goods and, as a result, increase their money holdings in proportion to their increased desire to spend. If these newly putchased goods are impotted of drawn from domestic inventories of previously produced goods, GNP will remain unchanged while the demand for money rises. Consequently, the usual measure of velocity would decline, while an alternative measure based on total transactions would remain unchanged. Thus, using GNP as the transactions measure to calculate velocity may produce sizable swings in velocity whenever there are large swings in inventories or net exports. Some analysts have argued that gross domestic final demand (GDFD), which equals GNP minus inventory adjustments and net exports, is preferable to GNP as the transactions proxy." Unfortunately, the substitution of GDFD for GNP does not explain the velocity puzzle of the 1980 s. As chart 3 indicates, this velocity measure performs essentially the same as the usual measure both before and after 1981. Consequently, simply replacing GNP with GDFD does not explain the protracted velocity decline during the $1980 s^{6}$

\footnotetext{
3See the appendix to Thornton (1983) for an iltustration of the specification problem involved in finding the appropriate measure of "income."

4There are two distinct, though not mutually exclusive theories of the demand for money: the transactions approach and the asset ap. proach. The asset approach emphasizes the role of money as an asset and, hence, as an alternative way of holding weatth. The transactions approach emphasizes the role of money as a medium of exchange. For a useful discussion of this distinction in relation to the velocity issue, see Spindt (1985).

Fadecki and Wenninger (1985)
}

ERasche (1986) also rejects this explanation for much the same reason. 
Chort I

Velocity

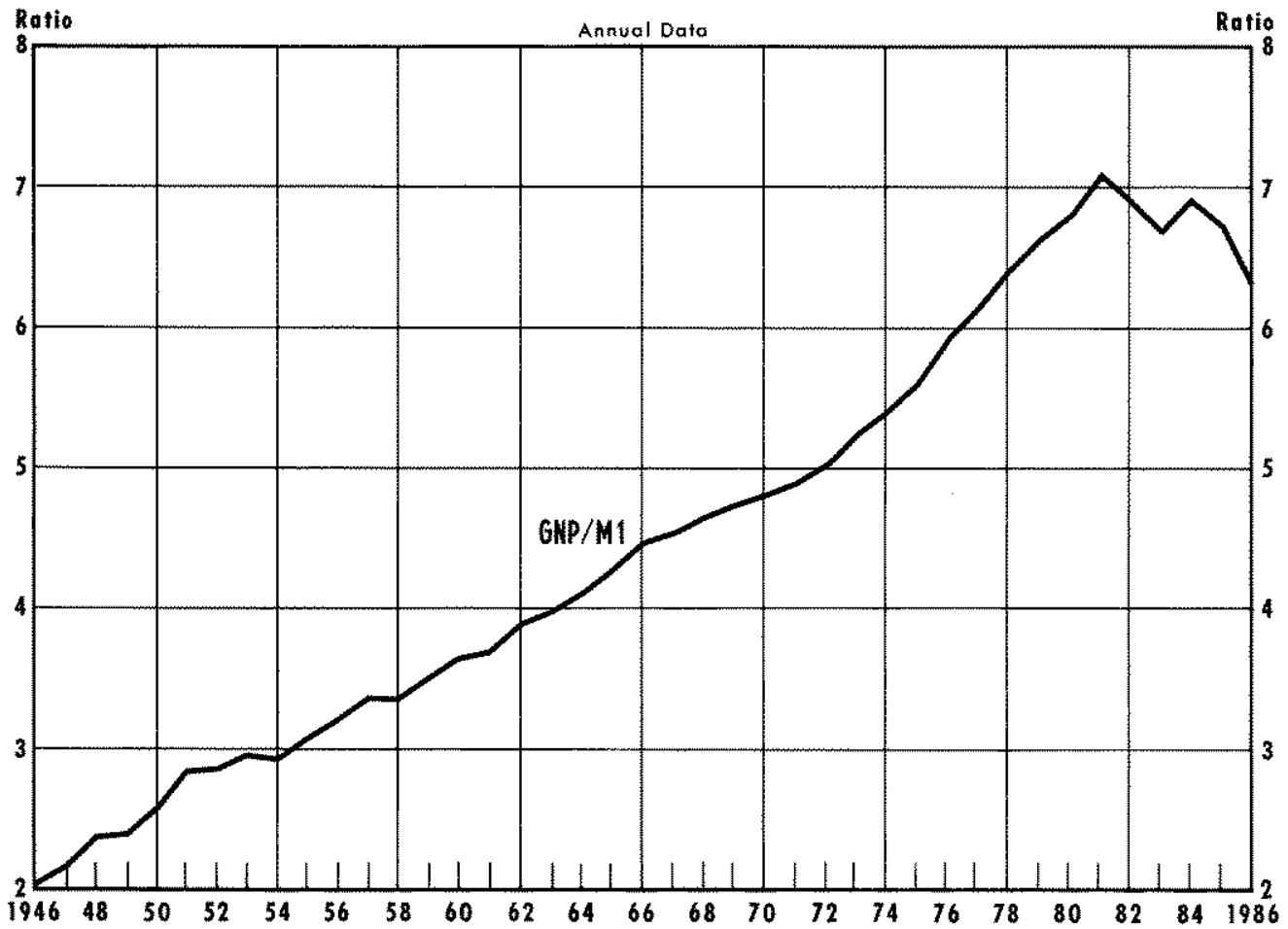

Chart 2

Inflation and Ml-Trend Growth

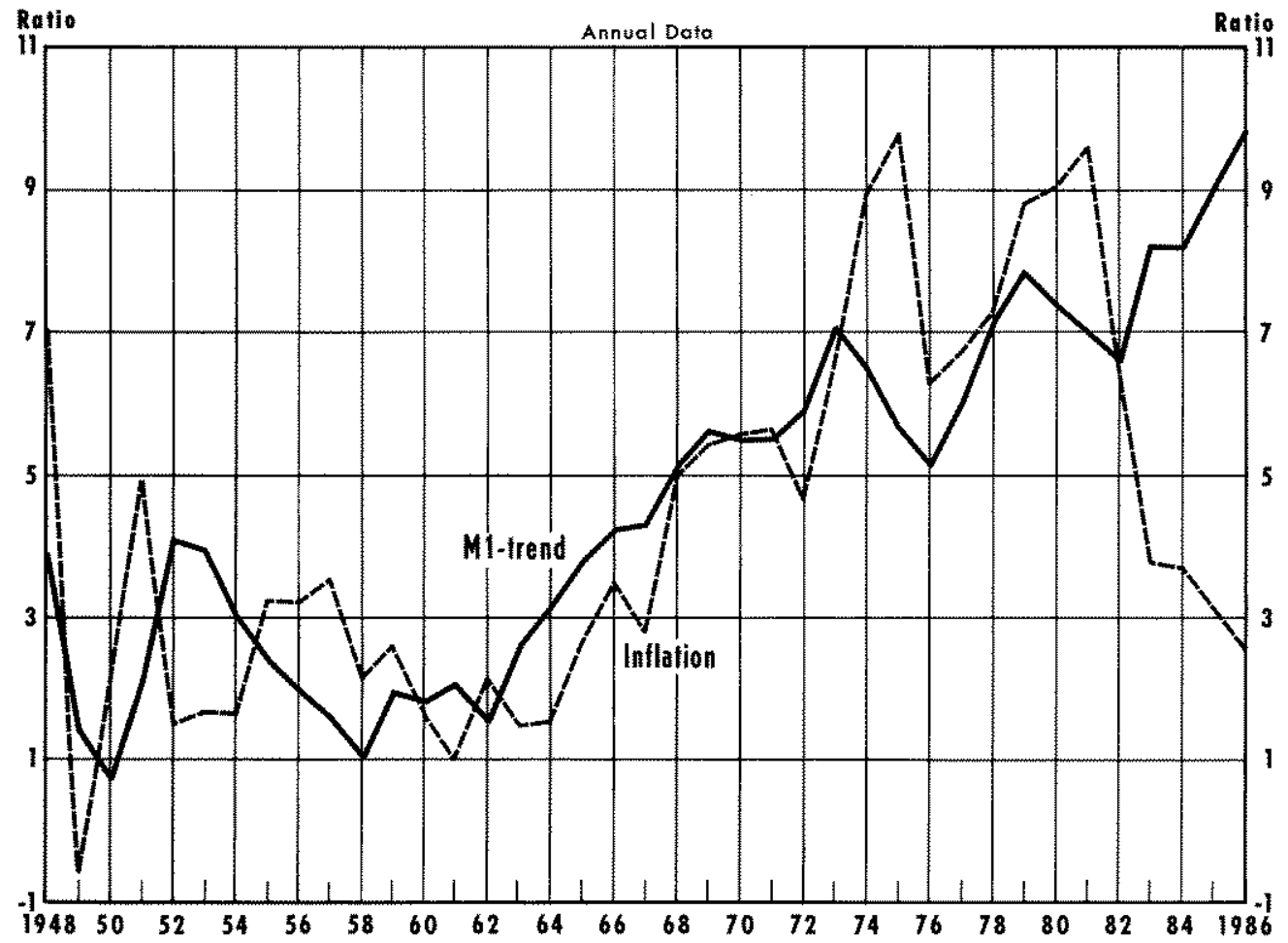




\section{Chat 3 \\ Velocities of GNP and GDFD}

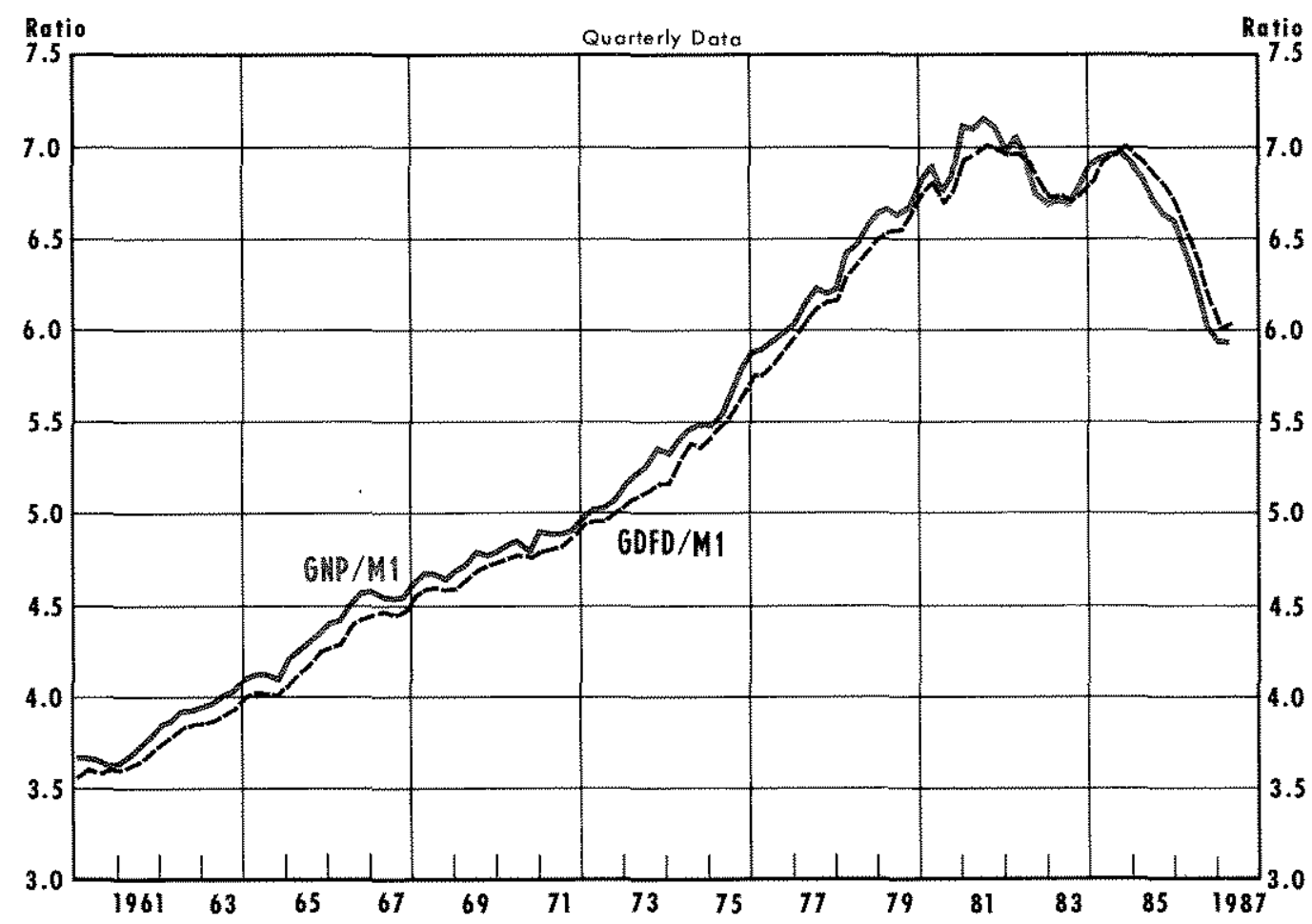

Recently, McGibany and Nourzad (1985) have offered another variant of the specification problem. They too argue that the demand for money is based on expenditures instead of current income or GNP. In their view, the 1980 tax cut initially increased disposable personal and business income relative to GNP and, hence, raised desired expenditures relative to GNP; consequently, the tax cut increased the demand for money, resulting in a fall in velocity.

One way to evaluate this explanation is to look at the ratio of disposable petsonal income to GNP. If their explanation is valid, this ratio should increase when velocity is falling and decrease when velocity is rising. As chart 4 indicates, however, this has not generally happened during the 1980s. While there was an initial expansion in disposable income following the tax cut, the ratio of disposable income to GNP has generally declined since 1982."

${ }^{7}$ Recently, McGibany and Nourzad (\$986) have provided estimates indicating that the demand for money is inversely related to the average tax rate.

${ }^{\text {B}}$ Rasche (forthcorning) rejects the tax cut hypothesis by arguing that, for it to explain the velocity decline, marginal tax rates would have had to have fallen continuously over the 1980 s.
Others have argued that the recent velocity decline is related to a sharp rise in financial transactions relative to total output. According to this view, the rise in financial transactions caused an increase in the demand for money relative 10 GNP. One way to assess this claim is to compare velocity measures using broad measures of financial and non-financial transactions in place of GNP. These alternatives are presented in chart 5 . The non-financial transactions velocity measure shows the same pattern as the GNP velocity measure. Consequently, explanations of the velocity puzzle that rely on the recent slowing of $\mathrm{GNP}$ growth relative to the growth of more general nonfinancial transactions measures are implausible.

The financial transactions velocity measure does not show the downturn in the 1980 s that characterizes the non-finaricial and GNP-based velocity measures. Nor, however, does it show substantial increases during the 1980 s which would be required if the rise in financial transactions is to account for the decline in M1 velocity. In fact, the annual growth rate of the financial transactions velocity measure has averaged

These data were obtained from the Board of Governors of the Federal Reserve System. 


\section{Chart 4}

Ratios of GNP/MI and Disposable Income/GNP

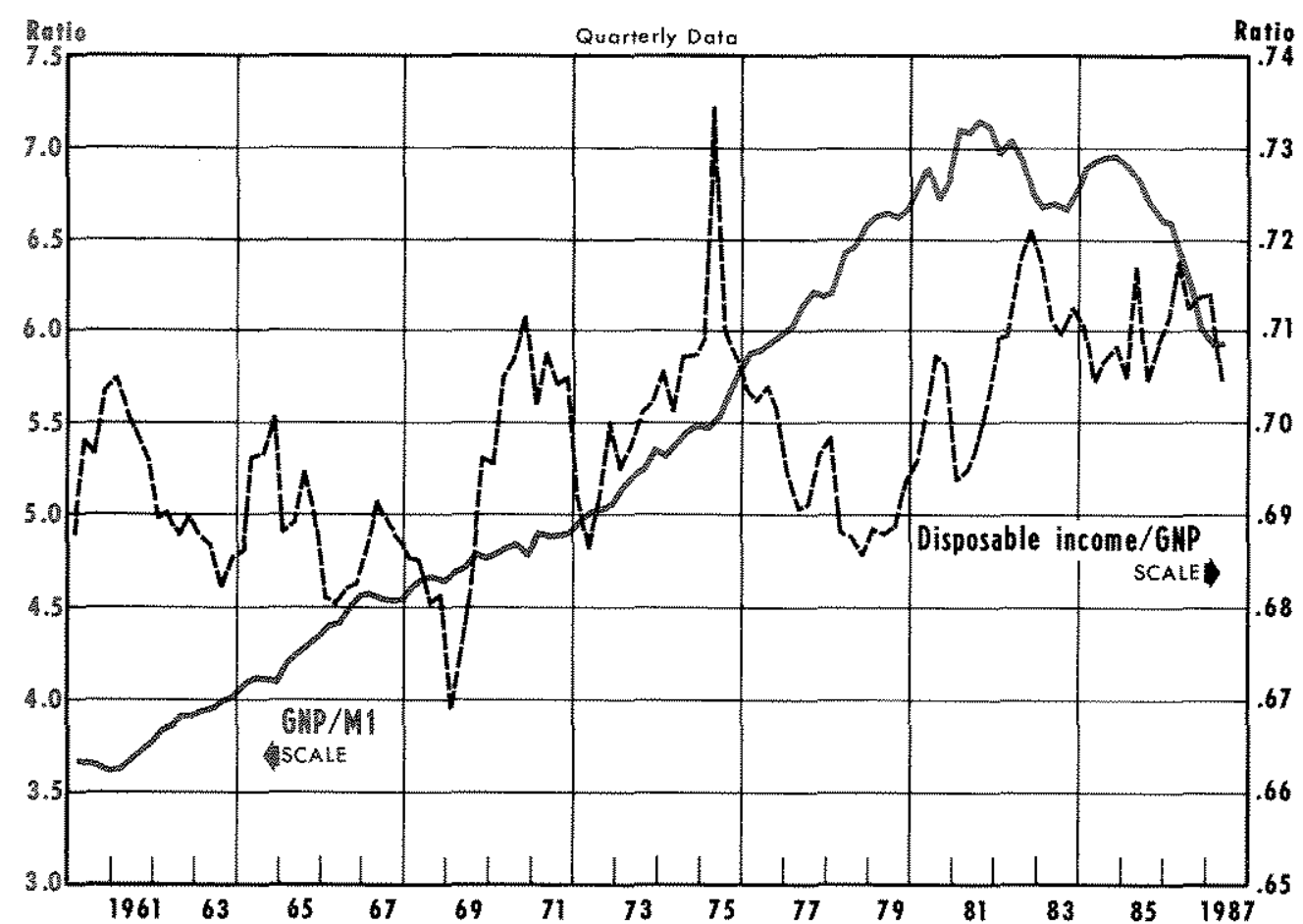

Chart 5

Velocities of Financial and Nonfinancial Transaction Debits

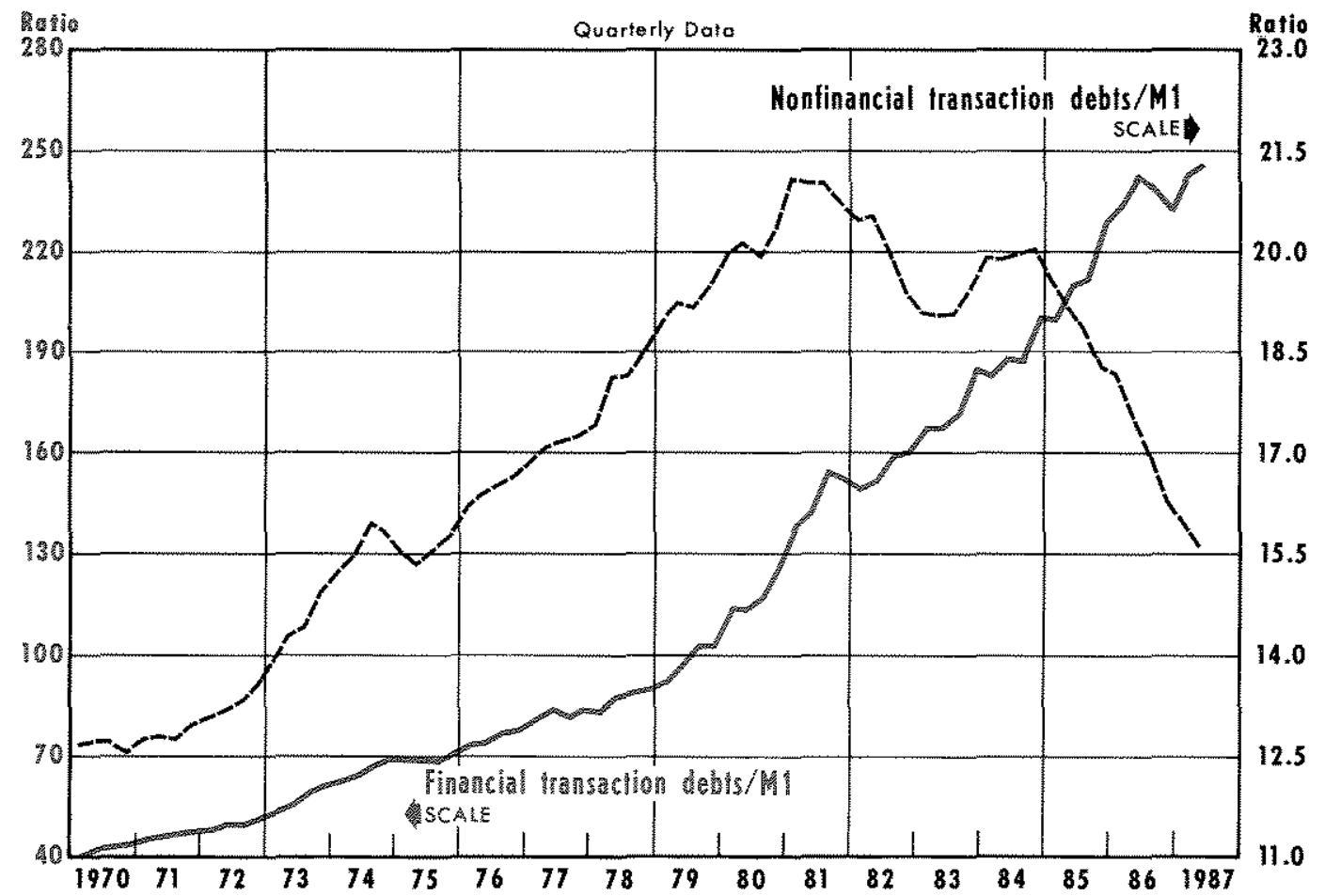


Charto

\section{Ratios of GNP/MI and NYSE/GNP}

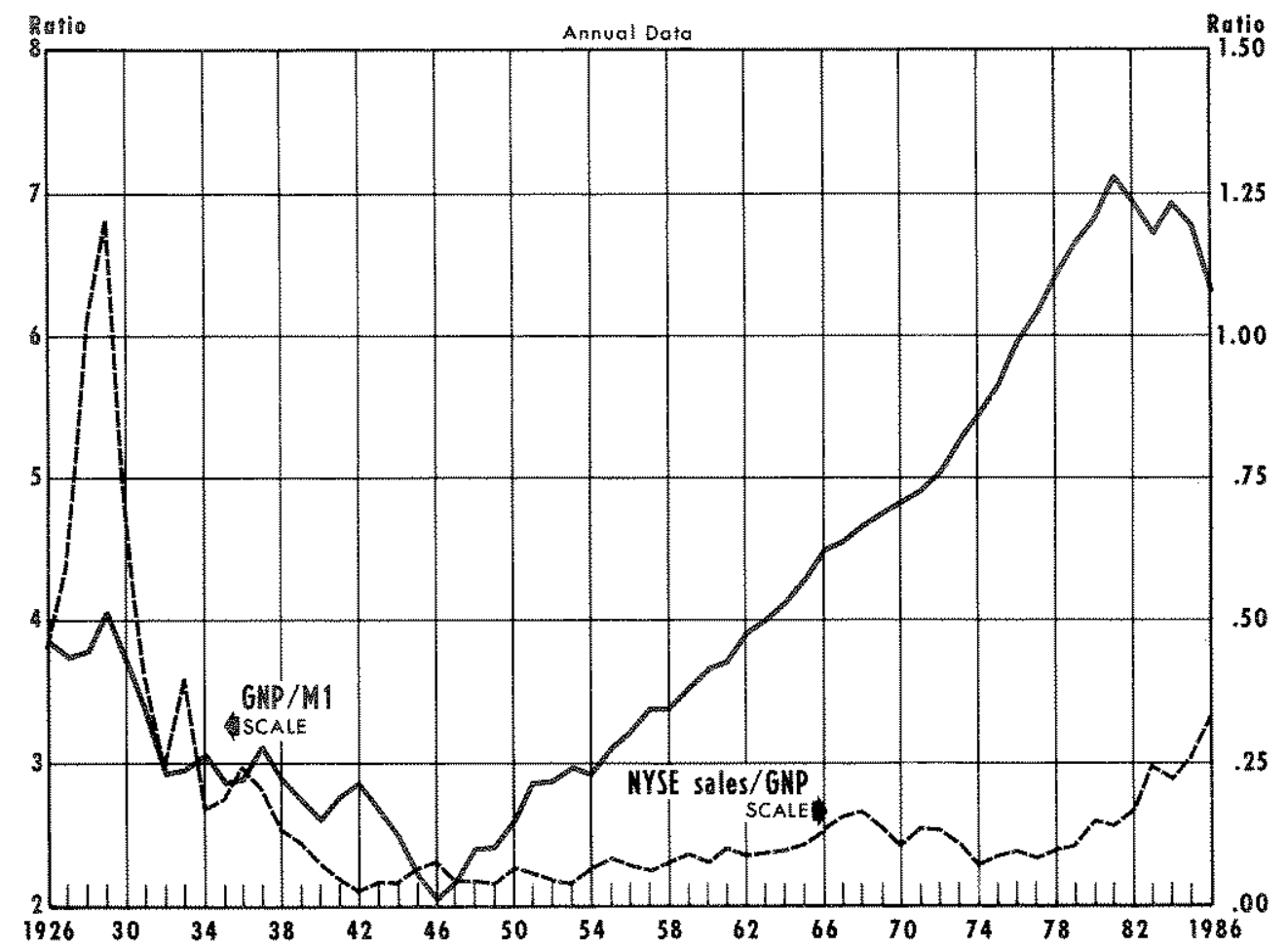

about 10 percent since 1981, somewhat below its 12 percent annual growth rate from 1970 to 1981 . If this measure accurately represents total financial transactions, its velocity movement does not support the view that the velocity problem resulted from a shift from non-financial transactions to financial transactions.

A somewhat different way to assess whether a rise in financial transactions produced the fall in velocity is shown in chart 6 ; it compares the movement of veloeity with that of the annual ratio of the value of shares sold on the New York Stock Exchange (NYSE) to GNP since 1926." While the ratio of NYSE sales to GNP has risen somewhat during the 1980 s, there has been no consistent relationship between this ratio and velocity over the past 60 years.

\section{GNP W. Wealth}

Another potential specification problem arises from the use of GNP to calculate velocity instead of using a

\footnotetext{
${ }^{10}$ It has been argued that the recent decline in velocity can be explained by the rise in stock market transactions, see Morgan Guarantee (1986)
}

measure of "permanent income" or wealth. The permanent income theory of consumer demand suggests that individuals primarily base their consumption decisions on their permanent income or wealth, rather than on curent income. Analogously, the demand for money may be more closely related to permanent income or wealth. ${ }^{73}$ Panel $A$ in figure 1 illustrates the theoretical telationship between pemanent incone and measured income during cyclical huctuations. If the demand for money depends upon pemanent income, it will fluctuate less than will curent income over the business cycle. Thus, measured velocity will rise fall as measured income increases decreases) relative to permanent income because the amount of money held will change less than measured income.

Chart 7 displays both the usual velocity measure and one based on permanent income estimates. ${ }^{2}$ Once again, it does not appear that the velocity decline in the 1980 s is explained by movements in cur-

\footnotetext{
"For example, see Friedman and Schwartz (1982, p. 38).

"The measure of permanent income used here was suggested by Darby $(1972)$.
} 
Figure 1

Cyclical Movement in Actual GNP and Measured Velocify and the Effect of a One-Time Increase in Permanent Income

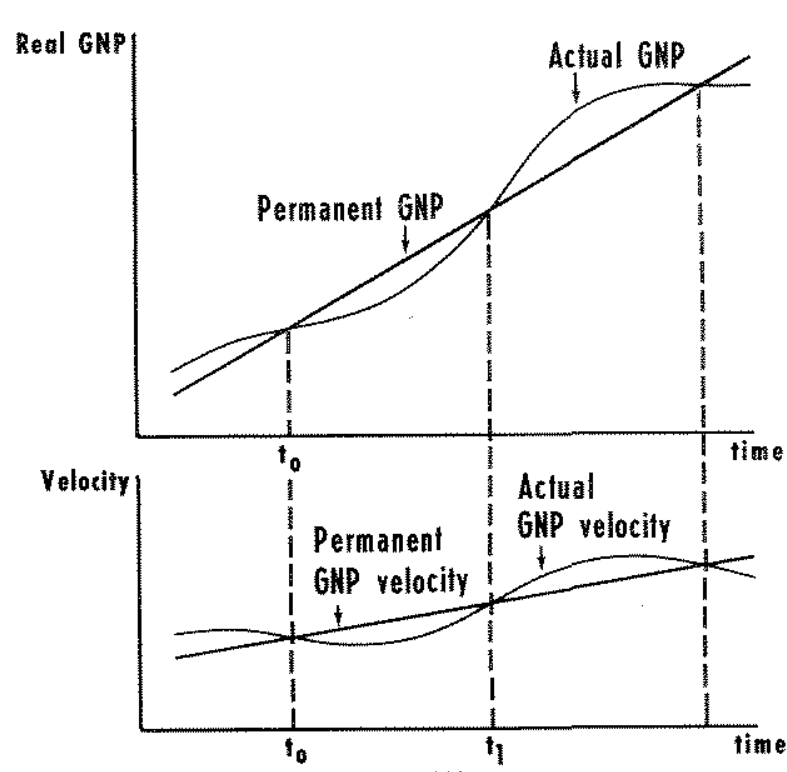

(A)

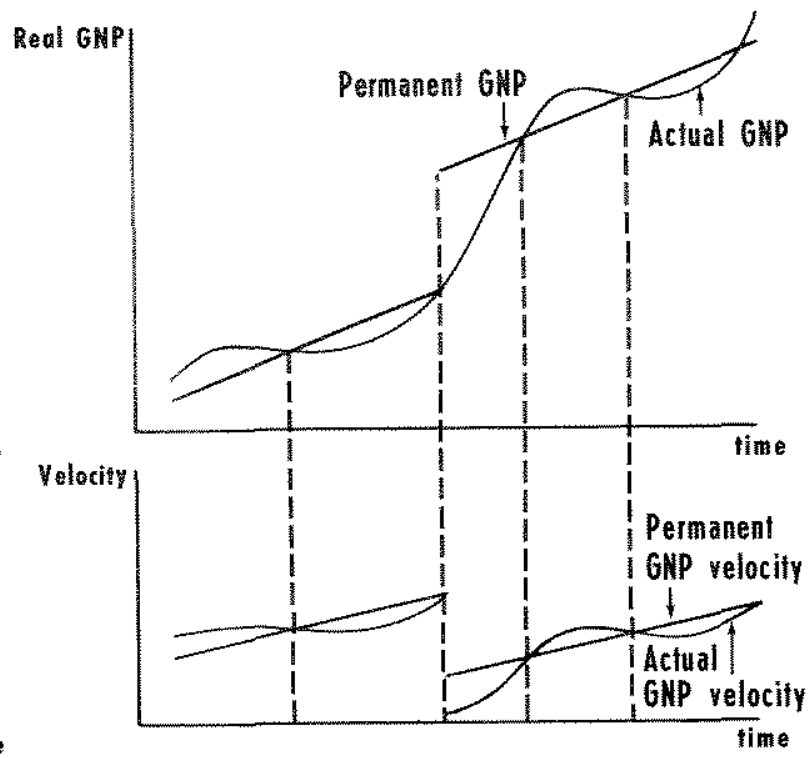

(B)

Chart 7

Velocities of GNP/MI and Permanent Income/MI

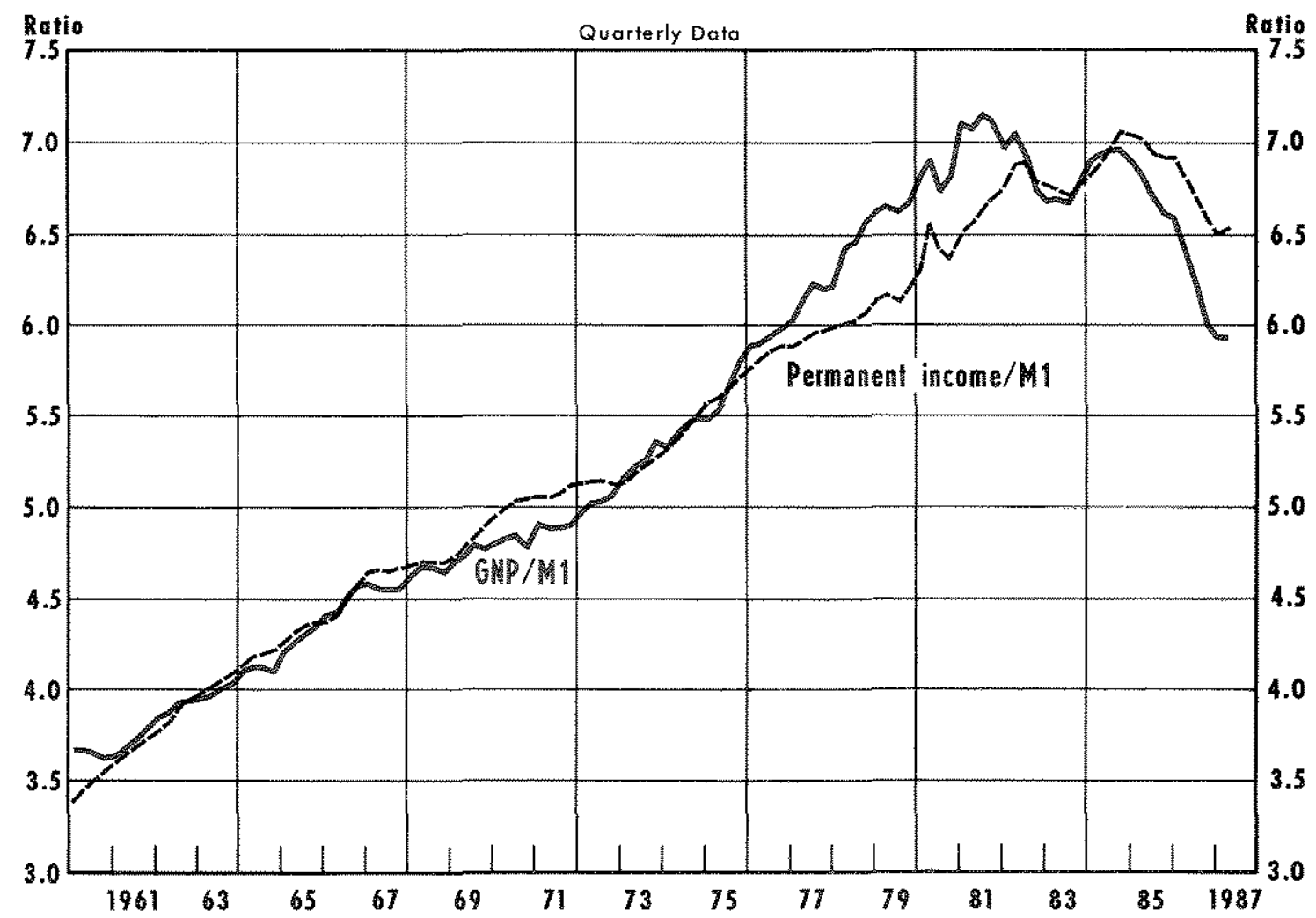


rent relative to permanent income. Although the downturns in the permanent income velocity measure are less pronounced than those in the current income velocity measure, the general downward shift in velocity during the 1980 s shows up cleary in the permanent income velocity measure.

There is an explanation consistent with the permanent income or wealth approach to the demand for money and the observed decline in the income velocm ity of money in recent years. Suppose that a rise in permanent income or wealth relative to curent income produced a sharp cise in the demand for money ${ }^{1:}$ In this event, depicted in panel $B$ in figure 1 . there would be an associated drop in curvent income velocity

Because weath is the present value of the expected future net income, it will increase either if expected income increases or the expected real interest rate used to discount future income declines. If there was a rise in expected income without a corresponding increase in measured income during the 1980 s, velocity would have fallen as the demand for money increased relative to GNP. Eventually, measured income will rise or expected income will decline as individuals realize that their expectations will be unfulflled ${ }^{*}$ Consequently, after sufficient time has elapsed, velocity will return to its former path.

If the rise in wealth is due solely to a sharp fall in society's preference for current relative to future con" sumption, however, the path of measured income would be unaffected and the level of velocity wolld be permanently below its former path. This possibility seems unlikely, because it implies a pemanent fall in the real interest rate.",

73asche (1986). Santoni (1987) and Kopcke (1986) also consider the wealth exptanation. Though their approaches are different, both Rasche and Santoni reject the wealth explanation for the velocity puzzle. Kopcke, on the other hand, finds evidence to support it. His wealth measure, however, includes financial assets that have off setting liablities; consequently, at best, it represents a proxy for financial transactions.

${ }^{14}$ Since wealth is the discounted present value of the stream of expected future income, an exogenous increase in wealth relative to current income can result onfy from a fall in the "real" interest rate or an increase in the expected future income stream. If these latter expectations are correct, measured income will eventually increase, and velocity will eventually return to iss long-run level as either the nominal money stock expands or the price level talls. If the expecta tions prove to be wrong, this too will be discovered and velocity will rise subsequently.

:The permanent fall in the real interest rate necessary to explain the fall in velocity is inconsistent with recent estimates of the ex ante real interest rates during the 1980 s. See Holland (1984).

\section{Potential problems with Using I}

Some have suggested that using $\mathrm{M} 1$ as the money stock measure when calculating velocity causes signifcant problems. They argue that the relevant monetary measure cannot be obtained simply by adding together the stocks of various "monetary" assers (cur" rency, checkable deposits, and so on), because each component may provide different quantities of monetary services per unit. Consequently, critics have suggested that an index of the monetary "services" provided by the stock of all relevant financial assets is preferable to the use of $\mathrm{M} 1$ for evaluating the relationship between money and spending or prices. If this criticism is valid, changes in "simple-sum" monetary aggregates like M1 and M2 may deviate markedly from changes in their underlying monetary services when ever substantial shitts among various monetary assets occur, in such cases, the usual measure of velocity may show sizable variations, while those based on the underying monetary services measures should be relatively stable."

Various monetary services indices (MSI) and the MO. measure have been developed; they are currently compiled and maintained by the Federal Reserve Board on an experimental basis. ${ }^{* 3}$ The MSI 1 measure is an index of the monetary services associated with components of the M1 money stock. The Mo measure is an index of all fnancial assets that can be directly used in transactions; it incorporates the components of M1 plus telephone transfers, money market mutual fund balances and money market deposit accounts. Chart 8 shows velocity measures based on the MSI1 and MO: These velocity measures show the same generat pattem for recen years as the usual M1 velocity measure. Similar results hold for broader monetary services indices. Consequently, despite their theoretica appeal, substituting monetary service flows for $\mathrm{M} 1$ in measures of velocity does not explain the recent behavior of velocity. ${ }^{23}$

\footnotetext{
18 See Batten and Thomton (1985) for a discussion of these issues.

${ }^{17}$ This need not be the case, however. See Milbourne (1986).

"The monetary services indices originally were called Divisia monetary aggregates; they were developed by William Barnet: (1980). The Mo meastre was developed by Paul Spirdt (1985). The current monetary services indices differ from the original Divisia measures in several respects; see Farr and Johnson (1985).

These alternative money meastures are only available since $1 / 1970$.

${ }^{20}$ This interpretation is irvariant to attemative meastres of income (permanent income or GDFD).
} 
Chart 8

\section{Velocities of Monetary Indexes MQ, MSI I and MI}

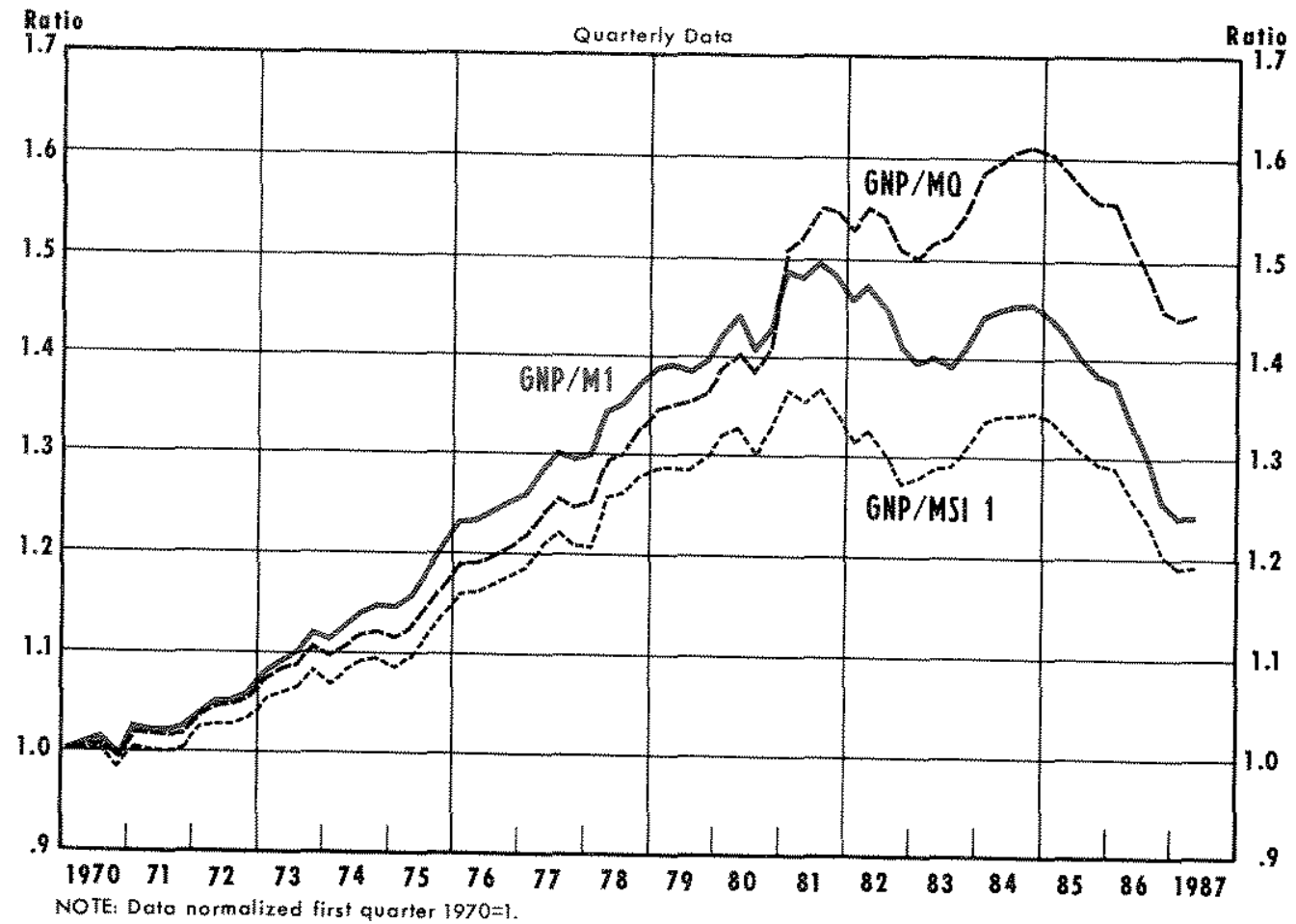

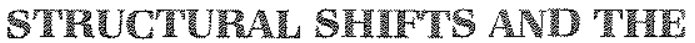 VEDOCH}

Some analysts have suggested that there have been one or more structural shifts in the money/income relationship. Unlike the specification problems previously discussed, this explanation presumes that the fundamental felationship between money and income has changed even if the demand for money is correctly specified in terms of M1 and GNP." (For a

${ }^{21}$ One stuctural shift argument not considered explicitly in the text was presented recently by Roley (1985). He suggested that the velocity puzzle of the 1980 s was actually caused by the welldocumented, albeit still unexplained, structural shift in the demand for money that took place in 1974. He argues that the downward shift in velocity in the 1982-83 period is consistent with the behavior of M1 velocity from 1974 through 1981; it is inconsistent, however, with $\mathrm{M} 1$ velocity before 1974. Roley's observation does not solve the velocity puzzle - atthough about 13 years have passed, we still don't know why money demand shifted in the mid-1970s.

Furthermore, if his suggestion were valid, the mid-1970s' velocity increase should have been as dramatic as its drop in the 1980s. A glance at chart 1 shows that this is not the case. Moreover. Roley's $M$ it series was derived from the flow of funds accounts. When conventional money stock and money demand equations are used instead, his results are not confirmed. different structural shift argument, see shaded insert on the opposile page.

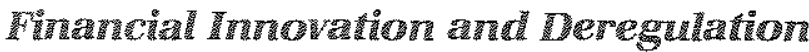

Several analysts have suggested that the introduclion of NOW's, Super NOWs and money market deposit accounts (MNDAs) and the removal of regulation $\mathrm{Q}$ interest rate ceilings in recent years have produced a shift in the relationships between $M 1$ and both spending and inflation. In particular, the redefinition of M1 to include interest-bearing checkable deposits NOWs and Super NOWs as well as non-interest-bearing demand deposits and currency is alleged to have altered significantly its "moneyness;" now M1 is presumed to include a significant amount of savings balances." Consequently, changes in $\mathrm{M} 1$ resulting from changes in these savings balances are likely to have a smaller

${ }_{22}^{2}$ The reader should note the similarity between this and the specification problem. The argument here is that savings balances are now effectively hidden among transactions balances so that a given level of interest-bearing checking account balances effectively can represent different amounts of "fransactions money." This is a specificaton problem, and results from a fundamental change in the institutional structure. 


\section{A T'ime Series Explanation of the Velocity Puzzle}

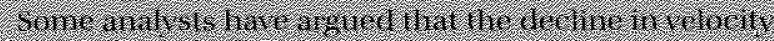

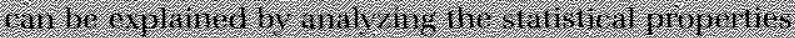

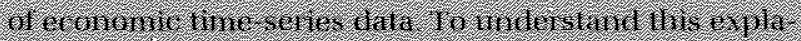

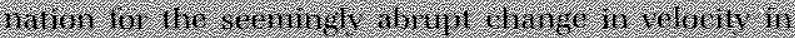

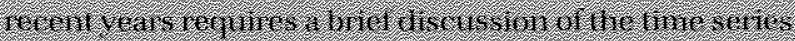

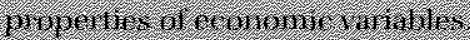

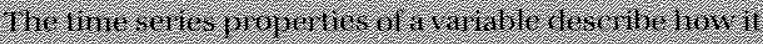

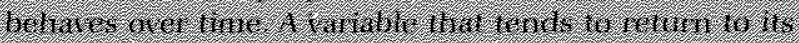

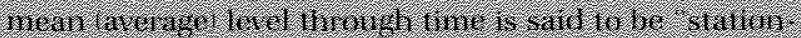

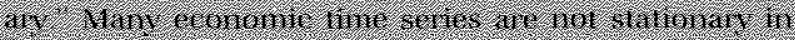

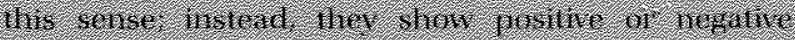

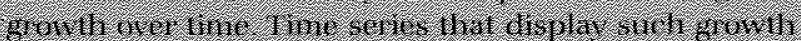

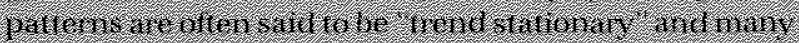

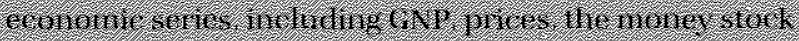

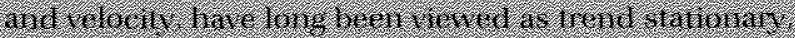

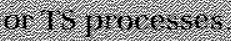

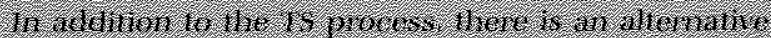

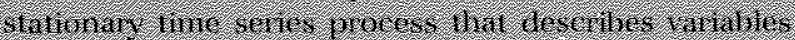

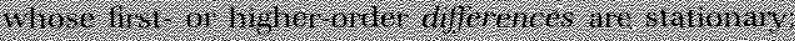

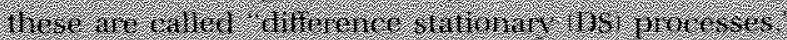

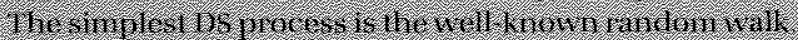

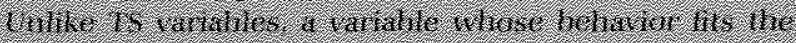

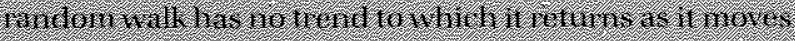
incting $\operatorname{tin}$

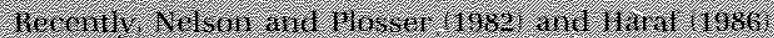

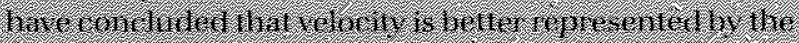

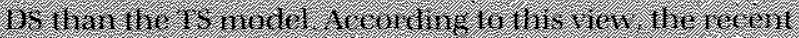

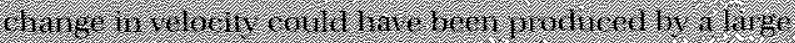

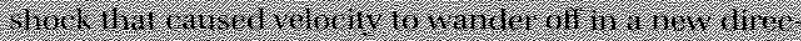

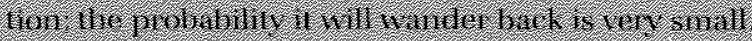

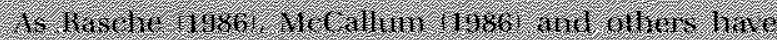

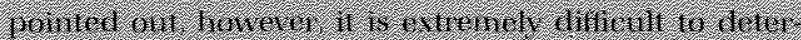

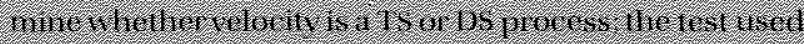

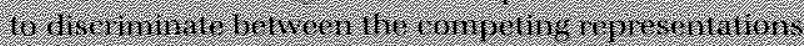

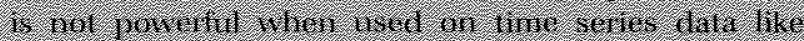

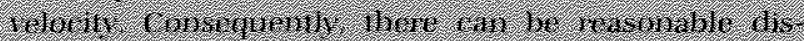

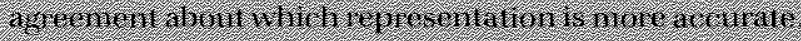

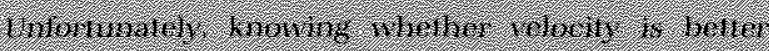

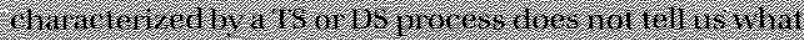

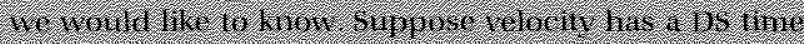

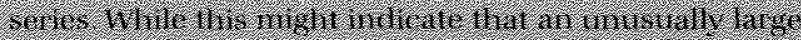

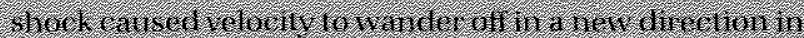

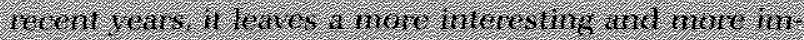

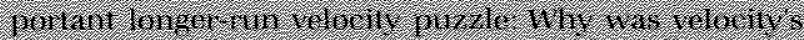

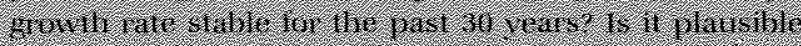

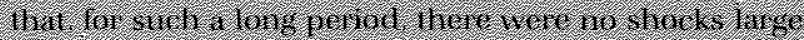

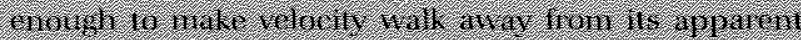

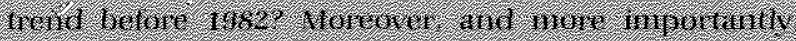

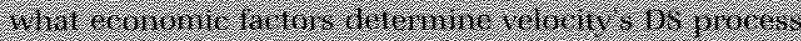

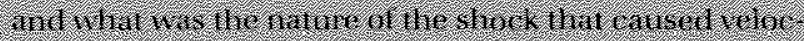

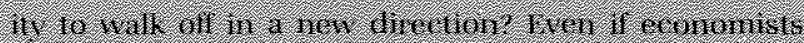

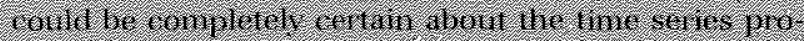

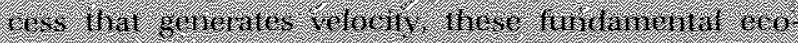

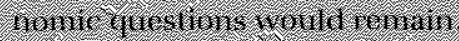

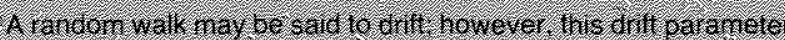

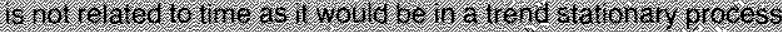

impact on output and prices than previously. ${ }^{2}$ Specifically, there may be extended periods when significant increases in M1 produce little or no associated growth in spending or inflation; on these occasions, velocity would decline substantially. ${ }^{24}$ Moreover, if the savings portion of M1 is related to GNP differently than its

23From another perspective, the growth rate of old M2 velocity had a Frend growth fate of zero; see ot (1982). Some have argued that new $M 1$ is close to old M2 - old M1 plus time and savings deposits, so perhaps the trend growth rate of its velocity, too, will be about zero. While the period since 1981 is too short to establish a trend the growth rate of the new $M 1$ velocity over this period has been about -2.4 percent

${ }^{24}$ While the experimental monetary aggregates should reduce or eliminate such problems, this does not seem to be the case. See Batten and Thornton (1985, pp. 32-33) for a discussion of this point. transaction components, the relationship between the growth rates of MI and GNP may be permanently altered.

"These savings balances appear only in the "other checkable deposits" (OCD) component of M1. Thus, the validity of this explanation can be examined by comparing the behavior of velocity measures using M1A which consists of currency and non-interestbearing checkable deposits) or currency alone with that of the M1 velocity measure during the 1980s. By increasing the cost of holding currency and demand deposits, the introduction of interest-bearing checkitble deposits (NOWs and Super NOWs) should have induced a relative shift from demand deposits and currency into these new accounts; this, in turn, should produce a significant rise in currency and M1A velocity measures. Once individuals' portfolios are 
Chort 9

\section{Velocities of GNP/M1 and GNP/MIA}

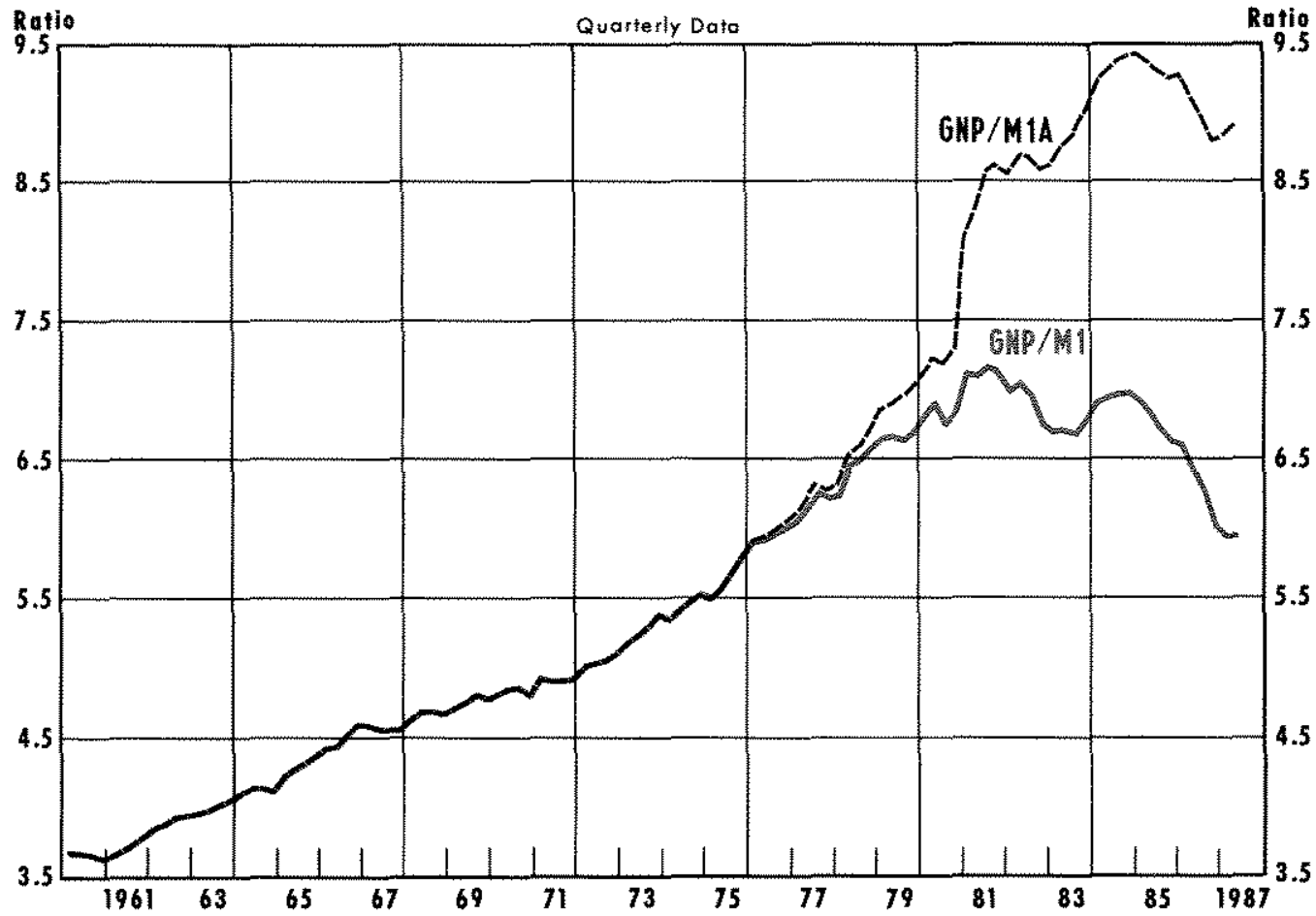

realigned, however, the prior currency and M1A veloc ${ }^{-}$ ity relationships should be restored.

Charts 9 and 10 show the M1A- and currencyvelocity measures. The M1A-velocity measure and, to a lesser extent, the currency-velocity measure rose sharply in the first quarter of 1981 when NOWs were introduced nationwide. Contrary to this structural shift explanation, however, both measures subse quently declined. ${ }^{35}$

Another explanation for the change in M1 velocity is an increased responsiveness of various M1 components to changes in the interest rate. According to this explanation, the financial innovations of the 1980s did not necessarily cause a downward shift in velocity due to a shift of savings balances into transactions accounts; instead, they altered the sensitivity of M1 balances to interest rates. Since the demand for money is inversely related to the interest rate, a decline in the

25is is the basis for Rasche's (1986) rejection of this explanation. The introduction of these new accounts, however, may have increased the interest elasticity of the demand for the M1A components. interest rate will cause the demand for money to rise relative to GNP and, hence, velocity will decline.

The theoretical basis for this argument stems from basic consumer demand theory, which argues that the responsiveness of the demand for a commodity to changes in its price increases with the number and closeness of substitute goods. The financial innovar tions of the 1980s produced new and close substitutes for traditional demand deposit and cumency components of $\mathrm{M} 1$. While the interest rate is not the price of money, it represents a significant opportunity cost for holding it. Consequently, the financial innovations of the 1980 s should have increased the responsiveness of some of the components of M1 to changes in the interest rate. The "other checkable-deposit" component of $M 1$ bears interest, and the interest rate paid on these deposits is now free to change with market rates ${ }^{23}$ Consequently, this component of $\mathrm{M} 1$ should be

Businesses cannot hold interest-bearing checking accounts. See Gibert and Holland (1984) for a summary of the major innovations and deregulations of the 1980s. Also, the currency component of M1 generally is more ctosely tied to reat income than to interest tate movements. 
Chort to

\section{Velocities of GNP/MI and GNP/Currency}

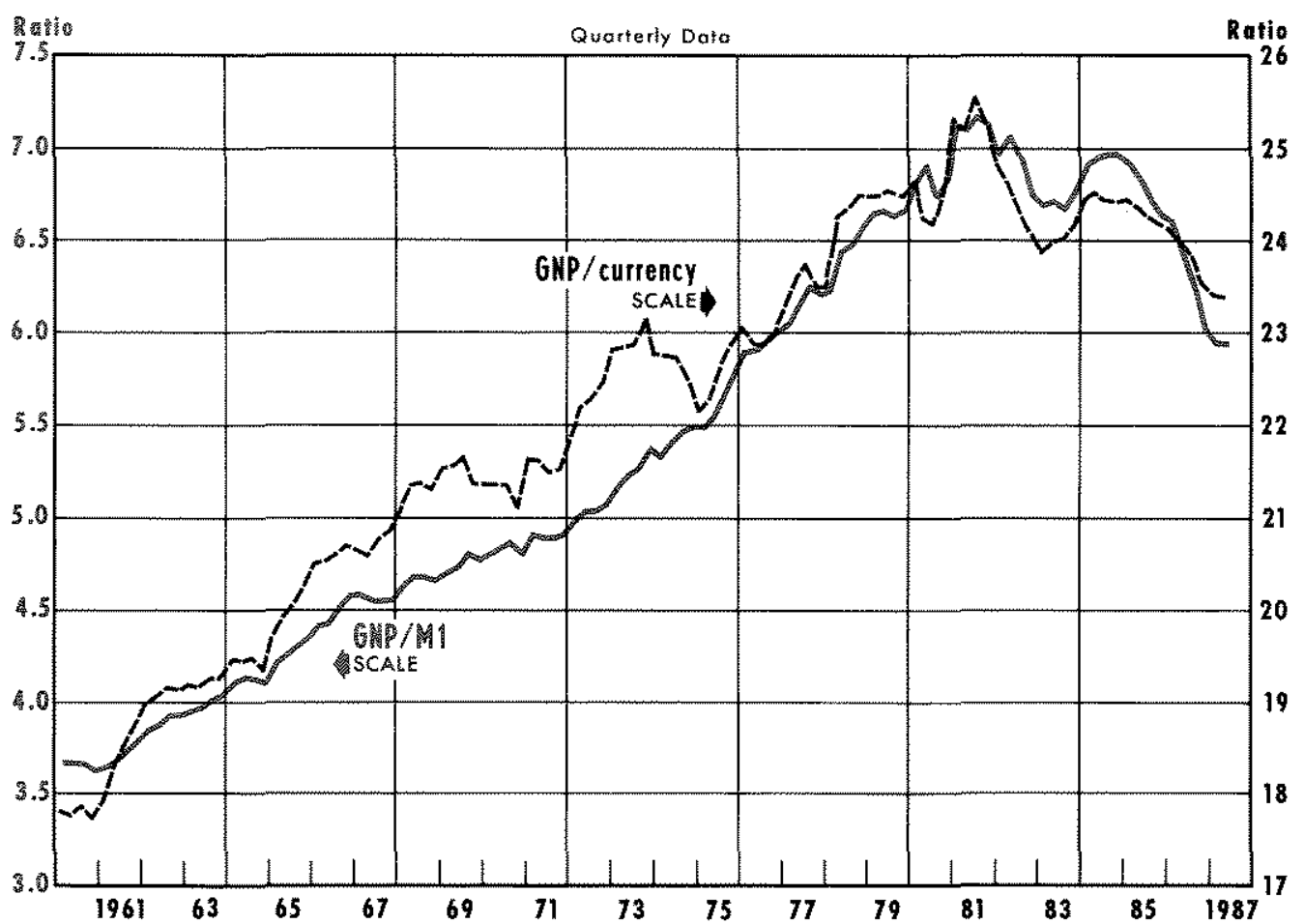

relatively unresponsive to interest rate movements. This could be mitigated by the fact that rates on these deposits appear to have been slow to adjust to changes in other market interest rates.

This view suggests that the relationship between velocity and interest rates should have strengthened since the financial innovations of the 1980s. Indeed, this pattern is reflected in Chart 11 , which shows M1 velocity and the three-month Treasury bill rate. Prior to 1981 , velocity appears to be unrelated to movements in the T-bill rate. Since 1981, however, the two have similar patterns. This is consistent with a number of studies which report an increased interest sensitivity of M1 balances during the 1980s, ${ }^{27}$ (Additional analysis is provided in the appendix. It remains to be seen whether the apparent change in M1's interest sensitivity alone can account for the aberrant behavior of M1 velocity.

${ }^{27}$ For example, Hetzel (1987). Trehan and Walsh (1987) and Rasche (1986). Rasche reports mixed results and concludes that this argument needs further study and analysis.

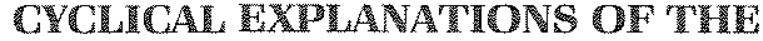 VETOCITV TYURZIIS}

Until now, we have assumed implicitly that the supply of money passively expands to meet society's demand. Another interpretation argues that substantial exogenous changes in the supply of M1 can induce cyclical swings in measured velocity because of their lagged effect on the economy. For example, an acceleration in the growth rate of $\mathrm{M} 1$ initially may produce a less than proportionate rise in the level of nominal GNP, and, thus, an initial decline in velocity. Eventually, however, when the monetary change has worked its way throughout the economy fully, the longer-run relationship between $M 1$ growth and the rate of spending is reestablished, and velocity returns to its long-run path.

This analysis can explain a continuous fall in velocty relative to its underlying trend only if $M 1$ growth is continuously accelerating. The "ever-and-ever-faster M1 growth" explanation for the velocity decline in the 


\section{Chartil}

\section{Velocity of GNP/MI and the Three-Month Treasury Bill Rate}

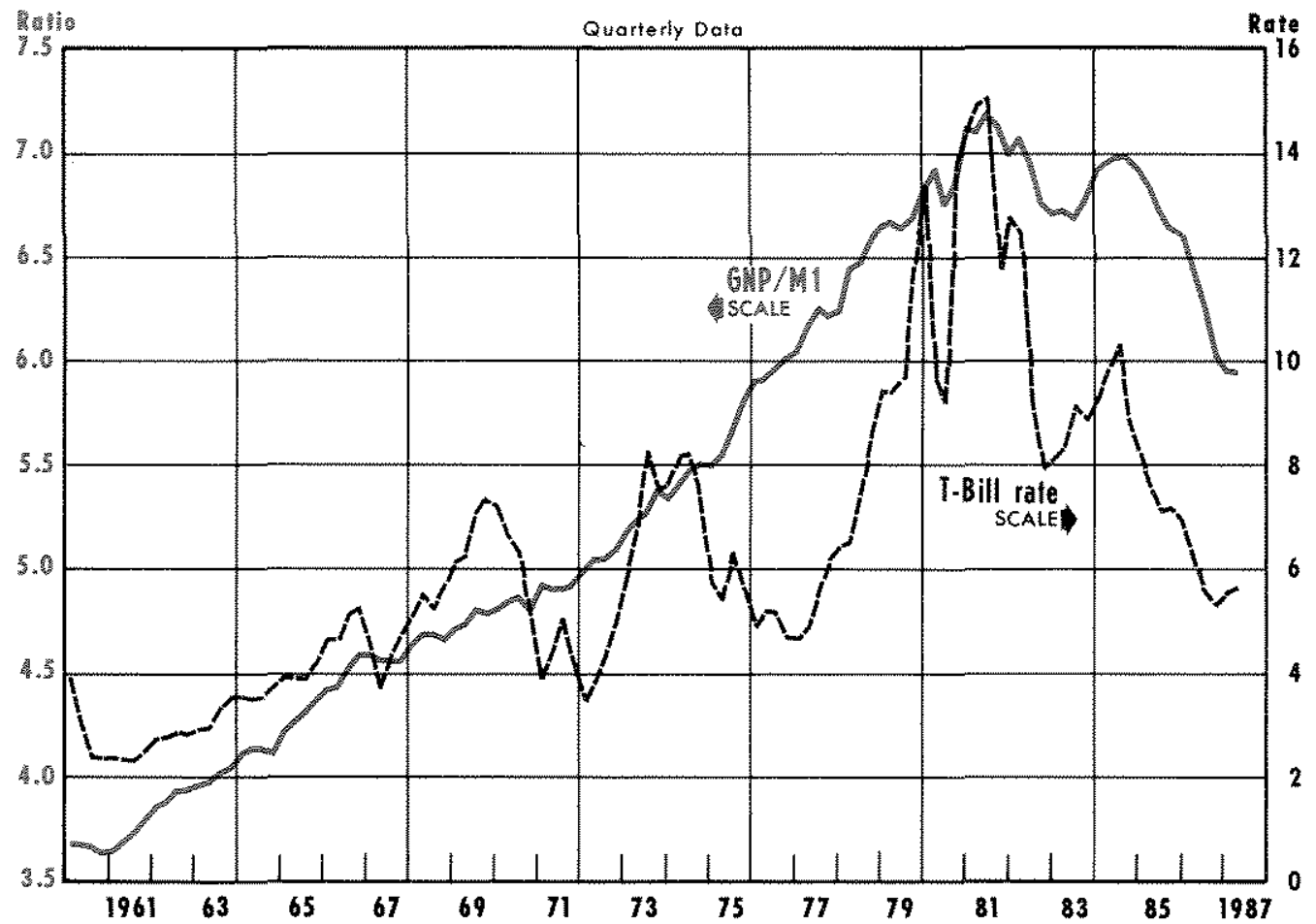

1980 s is examined in chart 12. Although money growth has been rapid since 1982 , it does not appear to have been accelerating fast enough relative to previous years to produce the recent sharp decline in velocity.

\section{Expected Inflation and Velocity}

Another explanation is that velocity's recent behavm ior results from changes in the public's expectations of inflation. According to this view, the demand for money is inversely related to the expected rate of

\footnotetext{
${ }^{28}$ There is a 4 percentage point spread between peak trend- $\mathrm{M} 1$ growth in the 1980 s and the late 1970 s. Hence, even if there were no nominal output response to the more rapid $M 1$ growth over the entire period, the acceleration in M1 growth, at most, could account for a 4 percentage point decline in trend velocity growth; that is, from about 3 percent to about -1 percent, In addition, this exptanation implies a significant lengthening in the estimated lag on money growth in the St. Louis equation during the 1980 s, which has not been confirmed

Another cyclical explanation not considered explicity in the tex has been suggested by Friedman (1983), Mascaro and Meltzer (1983) and Tatom (1983a, 1983b); in their view, an important influence on the demand for money is monetary uncertainly. Suppose that people increase their money holdings relative to their current income when they become more uncertain about their future incomes. If monetary uncertainty increased sufficiently in recent years, this could explain the velocity puzzle.
}

inflation. Thus, when inflation land presumably inflationary expectations as well is declining, the dem mand for money should rise, and the velocity of money should fall. Since the nominal interest rate can be thought of as composed of the real rate plus a premium for the expected rate of inflation, this explam nation is closely aligned to the interest sensitivity argument. The principal difference between then is that proponents of the expected-inflation explanation do not argue that the relationship has undergone a stuctural change," Judd (1983), Tatom (1983a, 1983b) and Friedman (1983) have argued that the decline in velocity in the $1981-83$ period can be attributed primarily to disinflation and the associated declne in market interest ates that substantially lowered the opportunity costs of holding money relative to GNP.

In one sense, this explanation is specious or, at the very least, suspicious if extended to velocity movements in more recent years. If inflationary expecta-

\footnotetext{
2a The expected rate of inflation also could have an inclependent effect on the demand for money, e.g., $m^{d}=f\left(i, \pi^{*}\right)$, where $\pi^{e}$ is the expected rate of intation. This issue has not been resolved.
} 
Chart 12

\section{Short-Run and Trend Growth of MI}

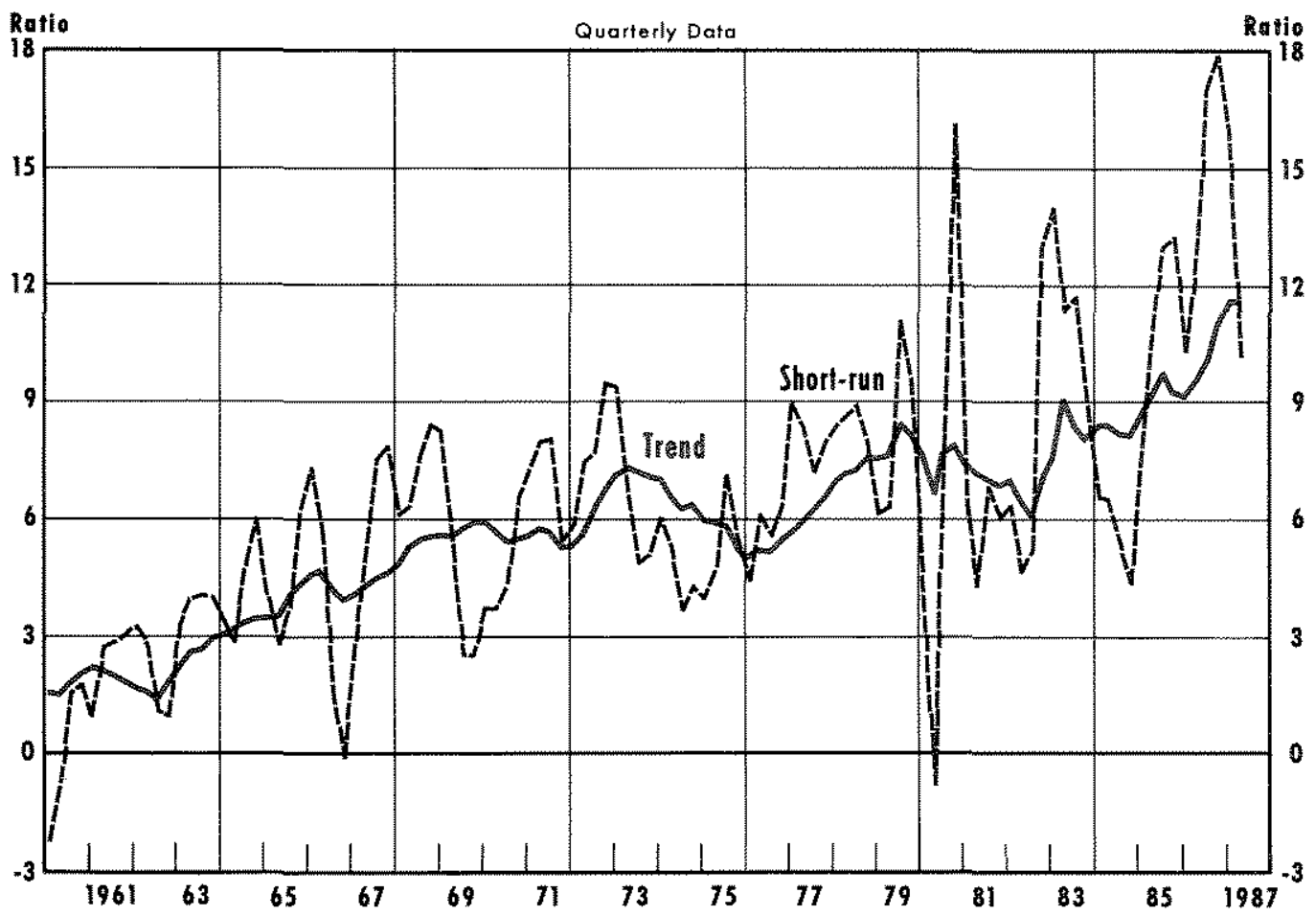

tions have fallen over the past five years, they must have done so for non-monetary reasons; as chart 2 shows, trend M1 growth has risen rapidly since 1983. These non-monetary factors must have been sufficiently powerful to have swamped the usual infuence that rapid trend money growth has on inflation and inflationary expectations.

Furthermore, if disinflation and declining nominal interest rates caused velocity to decine, then, by the same argument, velocity should have risen sharply when inflation accelerated and nominal interest rates rose during the 1970s. Unfortunately, this is not the case. Chart 13 shows M1-velocity and the ex post inflation rate. While velocity moves with the inflation rate after 1981 , it does not appear to be affected substantially by the inflation rate over the pre-financialinnovations period. Velocity growth during the $1970 \mathrm{~s}$ is not rapid enough to support this explanation.

Hetzel and Mehra (1985) suggest that the demand for money balances varies positively with the real value of the dollar in foreign exchange markets. Their explanation is based on the currency-substitution liypothesis, which states that different currencies are close substitutes for each other. In this explanation, the rise in the real exchange value of the dollar during the early 1980 s made holding dollars relatively more at tractive, increasing the demand for money relative to income and reducing velocily. ${ }^{3}$ Since the real exchange value of the dollar has generally moved with changes in the U.S. inflation rate, this argument is closely related to the inflation argument.

This explanation is examined in chart 14, which shows the movements in velocity and the nominal trade-weighted exchange rate since 1973. The nominal rather than the real exchange rate is used for two reasons. First, movements in the nominal exchange rate are more appropriate in assessing the relative retums on two different monies. Second, movements in the nominal and real trade-weighted exchange rates have been highly cotrelated since 1973 . Thus, the

\footnotetext{
30This argument does not seem firmly based in either the transactions or asset approaches to the demand for money. Except for some border situations, there is very limited substitutability between two currencies for transactions purposes. On the other hand, money balances, even interest-bearing checking accounts, are dominated on a risk-adjusted return criterion by other non-money assets. Consequently, it is unlikely that foreign money is hetd as an asset in portiolios.
} 
Chart 13

Velocity of GNP/MI and Inflation

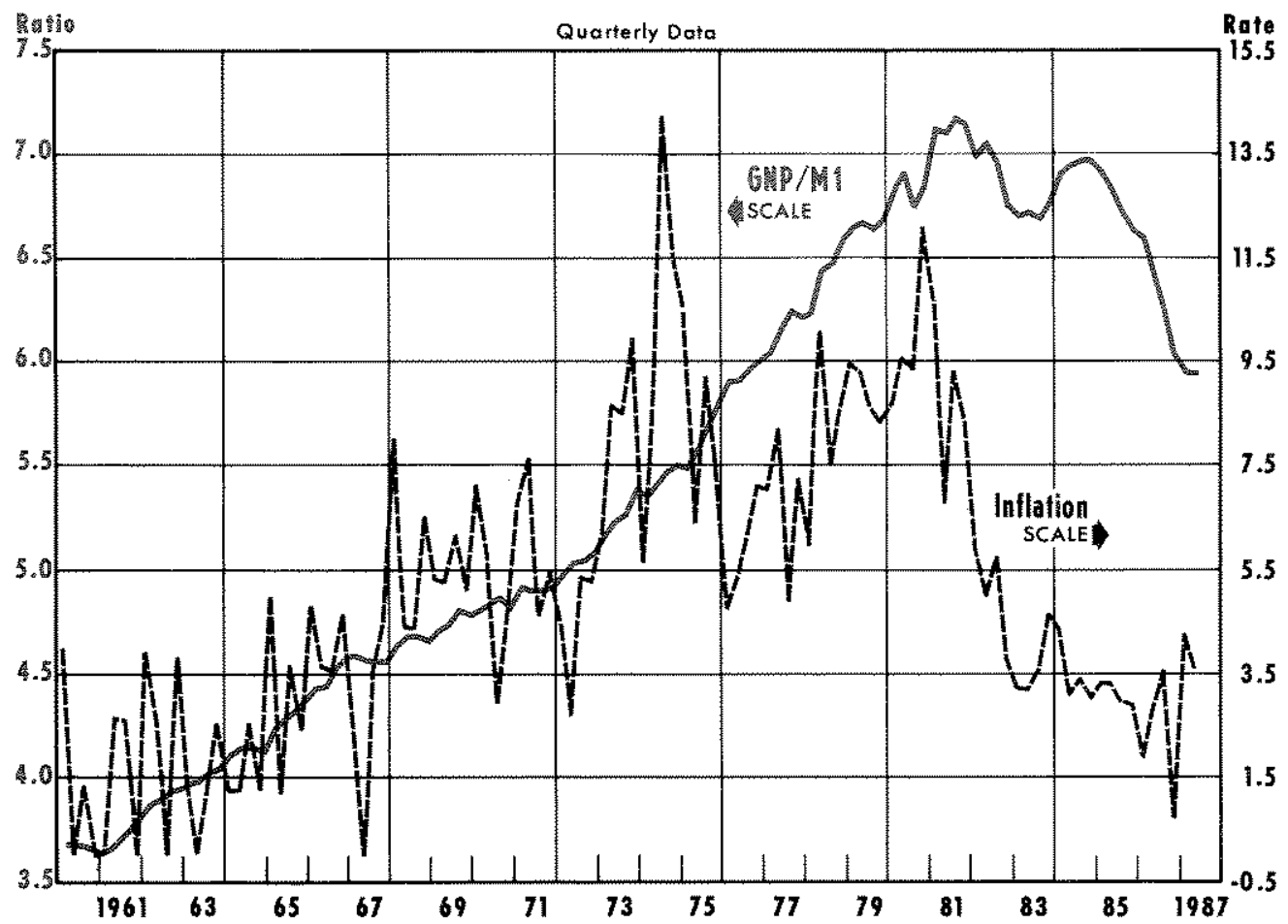

Chart 14

Velocity of GNP/MI and Trade-Weighted Exchange Rate

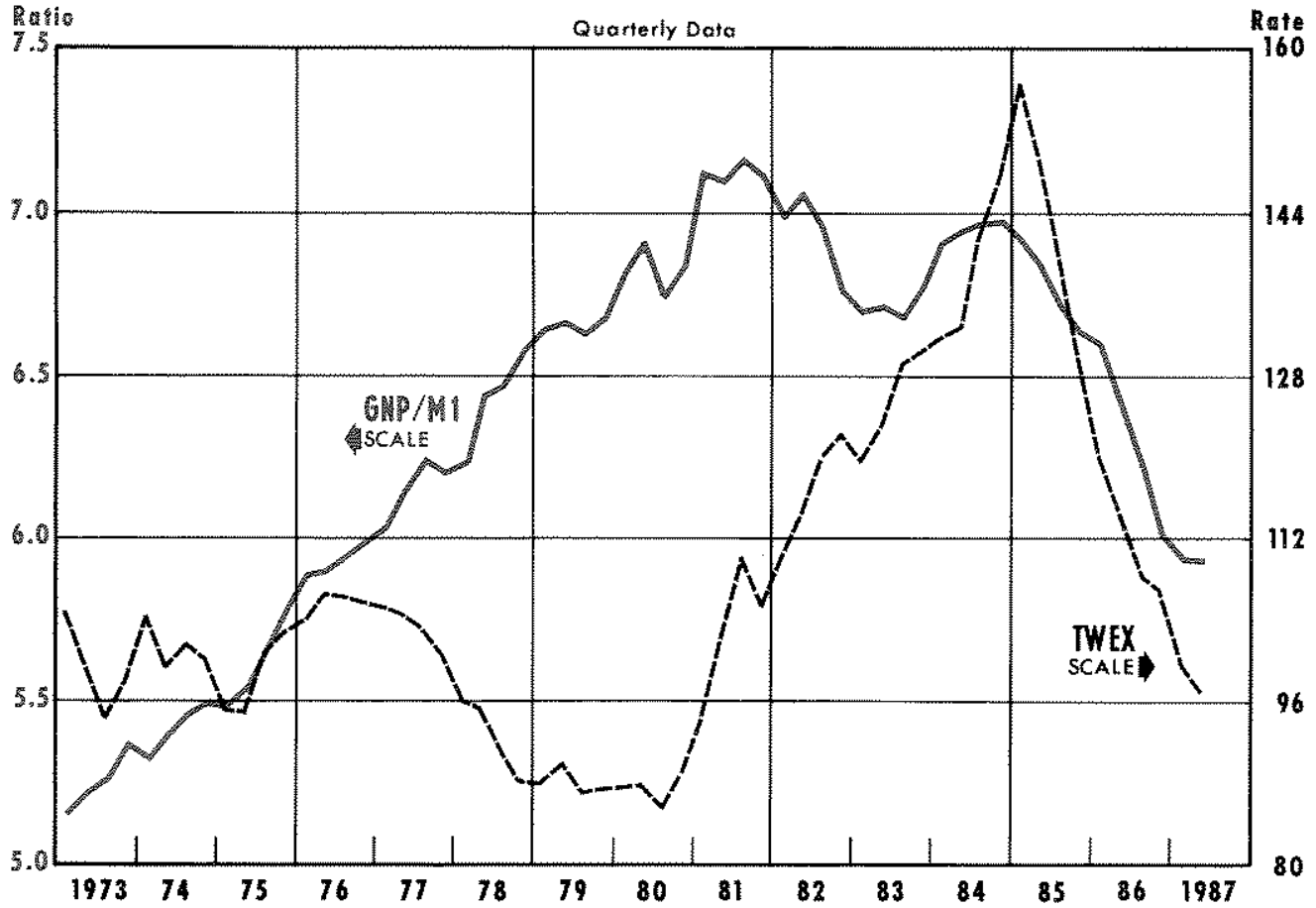


Chot is

Velocities of GNP/MIA and Permanent Income/MIA

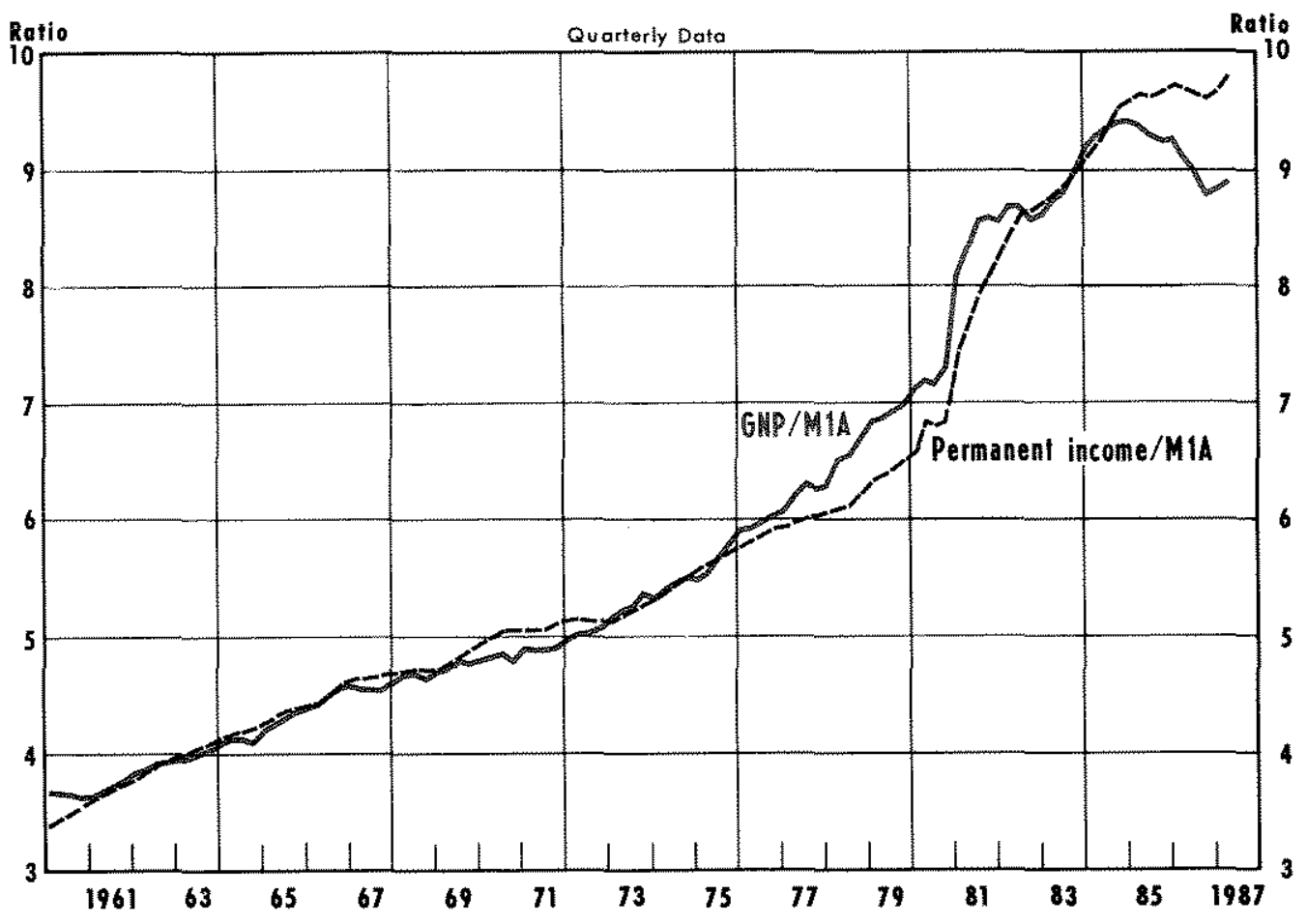

general pattem of exchange rate movements is the same whether the nominal or real exchange rate is used.

Chart 14 shows that the exchange rate explanation does not provide a satisfactory answer to the velocity puzzle. From 1973 to 1981 , exchange rate movements appear to have no influence on velocity. While velocity did decline from 1981 to 1983 , when the exchange rate was rising, it also fell sharply in 1985 and 1986 when the exchange rate was plummeting.

\section{TWO ENILANATIONS MAV BE BETVTP TMAN ONE}

Darby, Mascaro and Marlow (1987) have recently suggested that the velocity puzzle of the $1980 \mathrm{~s}$ is a product of financial innovation and cyclical effects in measured velocity. Incorporating both effects, chart 15 compares the usual velocity measure with a measure derived by dividing permanent income by MAA. There is a sharp rise in the permanent income/M1A velocity measure beginning with the nationwide introduction of NOW accounts. The movement in this measure following that event is consistent with a gradual adjustment to the initial and subsequent innovations that increased the cost of holding M1A, such as the introduction of Super NOW's in January 1984 and the reduction of the minimum balance requirements on these accounts in January 1985.

The permanent income/M1A velocity measure, unlike virtually all velocity measures shown in the previous charts, does not decline during the bulk of the 1980s. This measure does not decline until the last three quarters of 1986; however, it turns up again during the first half of 1987. Darby, Mascaro and Marlow suggest that the 1986 decline can be explained by the extremely rapid M1A growth during the last three quarters of the year. Consequently, a combination of the effects of financial innovations, cyclical movements in GNP and sharp acceleration in M1A growth could account for much of the velocity puzzle of the 1980s.

\section{SUMMARY AND CONCLUSIONS}

This article reviews a number of suggested explanations of the puzzling downturn in $\mathrm{M} 1$ velocity during 
the 1980 s and attempts to assess the credibility of each. Alone, none of these explanations can account for the behavior of M1 velocity. Perhaps, instead, sev eral infuences have combined to produce the anomalous velocity behavior that has puzzled many researchers.

If there are several infuences at work, financial innovations and cyclical variations in measured in come seem to be among the best candidates. This combination works well in explaining the velocity puzzle through the first quarter of 1986. When combined with cyclical variation in velocity induced by rapid money growth, it may explain the behavior of velocity through last year. Another explanation that deserves further scrutiny is the possible increased interest sensitivity of $M 1$ balances as a result of monetary innovations during the 1980 s.

\section{REFERENCES}

Barnett, William A. "Economıc Monetary Aggregation: An Application of Index Number and Aggregation Theory," Joumal of Econometrics (September 1980), pp. 11-48.

Batten, Dallas S., and Daniel L., Thornton. "Are Weighted Monetary Aggregates Better Than Simple-Sum M1?" this Review (June/July 1985), pp. $29-40$.

Darby, Michael R. "The Allocation of Transitory ncome Among Consumers' Assets," American Economic Review (December 1972), pp. 928-41.

Darby, Michael R., Angelo R. Mascaro, and Michael L. Marlow. "The Empirical Reliability of Monetary Aggregates as indicators: 1983-1986," U.S. Department of Treasury Research Paper No. 8701 (1987).

Darby, Michael R., Willam Poole, David E. Lindsey, Miton Friedman, and Michael $J$, Bazdarich. "Recent Behavior of the Velocity of Money, "Contemporary Policy Issues (January 1987), pp. 1-33.

Farr, Helen T, and Deborah Johnson. "Revisions in the Monetary Services (Divisia) Indexes of Monetary Aggregates," mimeo, Board of Governors of the Federal Reserve System (1985).

Friedman, Milton. "Why a Surge in Inflation is Likely Next Year," Wall Street Journal (September 1, 1983).

"The Quantity Theory of Money - A Restatement," in Studies in the Quantity Theory of Money (The University of Chicago Press, 1956), pp. 3-21.

Friedman, Mkton, and Arna J. Schwartz. Monetary Trends in the United States and the United Kingdom, 1867-1975 (University of Chicago Press, 1982).

Gilbert, F. Alton, and A. Steven Holland. "Has the Deregulation of Deposit Interest Rates Raised Mortgage Razes?" this Review (May 1984), pp. 5-15.

Haraf, Willam S. "The Recent Behavior of Velocity: Implications for Alternative Policy Rules," manuscript (1986).

Hetzel, Robert L. "Will Recent High Growth Rates of Money Revive Inflation?" Contemoorary Policy Issues (January 1987), pp. 4-53.

Hetzel, Robert L., and Yash Mehra. "U.S. Intlation and the Rea Exchange Rate," manuscript, July 1985.

Holland, A. Steven. "Real Interest Fates: What Accounts for Their Recent Rise?" this Review (December 1984), pp. 18-29.
Judd, John P. "The Recent Decline in Velocity: Instability in the Demand for Money or Inftation?" Federal Reserve Bank of San Francisco Economic Review (Summer 1983), pp. 12-19.

Kopcke, Richard W. "How Erratic is Money Growth?" Federal Rem serve Bank of Boston New England Economic Review (May/June 1986), pp. 3-20.

Kretzmer, Peter $E_{\text {, }}$ and Richard D. Porter. "Total Transaction Measures and $\mathrm{M} \dagger$ Growth?" Contemporary Policy Issues (January 1987), pp. 64-75.

Mascaro, Angelo, and Allan H. Meltzer. "Long- and Short-Term Interest Rates in a Risky World," Journal of Monetary Economics (November 1983), pp. 485-518.

McCalum, Bennett T. "On 'Real' and 'Sticky-Price' Theories of the Business Cycle," Journal of Money, Credit and Banking (November 1986), pp. $397-414$.

McGibany, James M., and Farrokh Nourzad. "Interest Rate Volatiity and the Demand for Money," The Quarterly Review of Economics and Business (Autumn 1986), pp. 73-83.

"Income Taxes and the Income Velocity of Money: An Empirical Analysis," Journal of Macroeconomics (Fall 1985), pp. 523-35.

Milbourne, Ross. "Financial Imnovations and the Demand for Liquid Assets," Journal of Money, Credit, and Banking (November 1986), pp. $506-11$.

Morgan Guarantee. "Demystifying Money's Explosive Growth," Morgan Economic Quarterly (March 1986). pp. 10-13.

Nelson, Charles, and Charles Plosser. "Trends and Random Walks in Macroeconomic time Series: Some Evidence and Implications," Journal of Monetary Economics (September 1982), pp. 139-62.

Ott, Mack. "Money, Credit and Velocity," this Review (May 1982), pp. 21-34.

Radecki, Lawrence $\mathrm{J}$, and John Wenninger. "Recent Instability in M1's Velocity," Federai Reserve Bank of New York Quarterly Review (Autumn 1985), pp. 16-22.

Rasche, Robert H. "M1-Velocity and Money Demand Functions: Do Stable Relationships Exist?": Journal of Monetary Economics (forthcoming).

"Velocity and the Choice of Policy Regimes," The Cato Joumal (Fall 1986), pp. 663-66.

Roley, Vance V. "The Demand for M1 by Households: An Evaluation of its Stability," Federal Reserve Bank of Kansas City Economic Review (April 1985), pp. 17-27.

Santoni, G. J. "Changes in Wealth and the Velocity of Money." this Review (Mazch 1987), pp. 16-26.

Spindt, Pauf A. "Money is What Money Does: Monetary Aggrega" tion and the Equation of Exchange," Journal of Political Economy (February 1985), pp. 175-204.

Tatom, John A. "Was the 1982 Velocity Decline Unusual?" this Review (August/September 1983a), pp. 5-15.

"Alternative Explanations of the 1982-83 Dectine in Velocity," in Monetary Targeting and Velocity, Conference Proceedings, Federal Reserve Bank of San Francisco, 1983b, pp. 2256.

Thornton, Daniel L. "Why Does Velocity Matter?" this Review (De. cember 1983), pp. 5-13.

Thornton, Daniel L., and Dallas S. Batten. "Lag Length Selection and Tests of Granger Causality Between Money and Income," Journal of Money, Credit and Banking (May 1985), pp. 164-78.

Trehan, Bharat, and Carl E. Walsh. "Portfolio Substitution and Recent M1 Behavior," Contemporary Policy Issues (January 1987), pp. 54-63. 


\section{Appendix}

To examine whether velocity has become more interest sensitive in the 1980 s, the growth rate of M1 velocity was regressed on distributed lags of its own past growth rate and changes in the three-month Treasury bill rate for three alternative periods from $1 / 1960$ to $1 / 1987$. The results are presented in table 1 . The lag length was determined separately for each period using the final prediction error criterion; see Thortuton and Batten (1985). The maximum lag length considered was 12 for the two longer periods and four for the shorter one. The pre-1980 results indicate that neither its own past growth nor that of short-term interest rates significantly influenced $\mathrm{M} 1$ velocity growth. The lag lengths selected were zero for velocity growth and the contemporaneous and first lag for the change in the Treasury bill rate. However, even though the lag coefficient on the change in the T-bill rate is both positive as expected and statistically significant at the 5 percent level, the hypothesis that the contemporaneous and lag coefficients are jointly insignificant cannot be rejected at the 5 percent level.

A considerably different result emerges when the regres- sion is extended to include the 1980s. The lag-length selection procedure now chose a sixth-otder lag for velocity growth and a fourth-order lag for the change in the T-bill rate. Moreover the hypothesis that these coefficients are jointly insignificant is rejected at the 5 percent level; contemporaneous and past changes in the Treasury bill rate exert a significant influence on current Mu velocity growth.

When the equation is estimated only for the period of the 1980 s, there is again evidence of a statistically significant effect of interest rates on $M 1$ velociry. Indeed, the sum of the distributed lag coefficients on the Treasury-bill rate is positive and significant, indicating a longer-run positive relationship between M1 velocity and interest rates that does not appear to have existed in the prior period. Hence, these results are consistent with the hypothesis that the interest sensitivity of M1 balances changed significantly following the monetary deregulation and financial innovations of the 1980s. If will take more research, however, to determine how much of the velocity puzzle can be attributed to this factor.

Table 1

Estimates of a Velocity Growth Rate Equation'

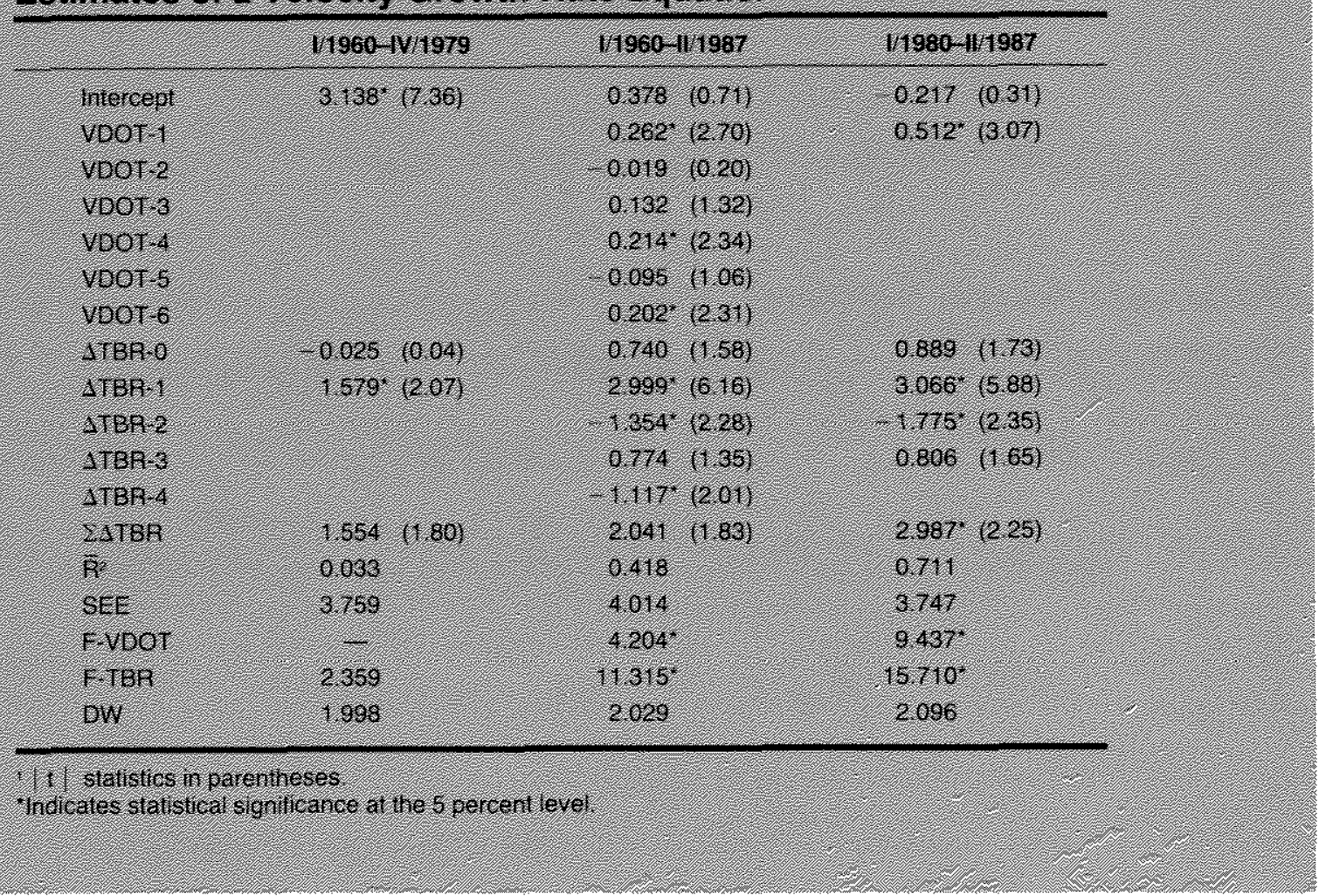

